\title{
Disqualification Decisions under the ICSID Convention and Arbitration Rules
}

This Chapter aims to distill a consistent approach to arbitrators' independence and impartiality from past decisions on disqualification requests. In a first part, the interpretation of the manifest lack requirement provided for in Article 57 ICSID Convention is scrutinized. The definition of this threshold (i.e. the burden of proof imposed on the challenging party) is crucial, because it determines the effectiveness of the right to an independent and impartial decision-maker. The second part of the Chapter inquires how specific categories of alleged conflict are dealt with. It seeks to derive consistency and predictability from the outcome or reasoning of disqualification decisions in particular constellations.

All disqualification decisions which have been published or discussed in scientific literature prior to December 1, 2016 are covered, provided that they make reference to the applicable threshold for arbitrator disqualification, or offer insight into the assessment of certain categories of challenge grounds. ${ }^{136}$

${ }_{13} 6$ Despite improvements in the transparency of ICSID proceedings, a significant number of challenge decisions remain unpublished. Chapter 2, Part 1 analyzes all decisions which offer insight into the interpretation of the manifest lack requirement. Unpublished decisions and requests which were dismissed because they were belated, or because the arbitrator had resigned in the meantime, are generally not taken into consideration. Chapter 2, Part 2 also takes unpublished decisions into account, provided that at least the grounds for the challenge and its outcome have been reported. Unpublished disqualification decisions which have been discussed on reporting websites which are not openly accessible, such as Investment Arbitration Reporter (www.iareporter.com) or Global Arbitration Review (www.globalarbitrationreview.com), are taken into account to the extent the author was able to access such reports.

For a comprehensive overview of all challenge decisions (including unpublished ones) and resignations, see Kinnear and Nitschke, supra note 13, at 61-79 (Annex 1); DAELE, supra note 51 . 


\section{Formally Inconsistent Interpretations of the Disqualification Threshold}

\subsection{Requirement of Strict Proof under Amco Asia}

The first arbitrator challenge under the ICSID Convention was made in Amco Asia. ${ }^{137}$ Indonesia requested the disqualification of Edward W. Rubin, the Claimant-appointed arbitrator in the case. Prior to his appointment as an arbitrator (but after the initiation of arbitration proceedings), ${ }^{138}$ Rubin had given tax advice to the controlling shareholder of the corporate Claimant. Furthermore, his law firm had shared office space and administrative services with counsel for Claimant for about half a year into the arbitration proceedings. A long-standing profit-sharing arrangement between the firms had been discontinued before the arbitration was initiated. Indonesia argued that these circumstances affected the arbitrator's independence. ${ }^{139}$

The unchallenged arbitrators dismissed the challenge for lack of a strict proof of actual bias. They required proof not only of the facts that indicated a lack of independence, but also of the arbitrator's actual lack of independence, which had to be “'manifest' or 'highly probable', not just 'possible' or 'quasicertain."'140 Justified doubts regarding the arbitrator's independence, based on the above-mentioned facts, were not considered to be sufficient. ${ }^{141}$

They elaborated that arbitrators could not be disqualified based solely on their relationship with the appointing party - irrespective of its character and extent - since the system of party-appointments inherently presumed such acquaintances. ${ }^{142}$ The indiscriminate nature of this position is irreconcilable with the tribunal's insistence on the importance of "an absolute impartiality ... of all the members of an arbitral tribunal" in the same decision. ${ }^{143}$

137 Amco Asia Corporation and others v. Republic of Indonesia (Amco Asia), ICsid Case No. ARB $/ 81 / 1$, Decision on the Proposal to Disqualify an Arbitrator (June 24, 1982), cited in Tupman, supra note 43, at 45. See also LUtTRELL, supra note 31, at 226.

138 Compañia de Aguas del Aconquija S.A. and Vivendi Universal S.A. v. Argentine Republic (Vivendi), ICsid Case No. ARB/97/3, Decision on Challenge to the President of the Committee (Sept. 24, 2001), \ 21.

139 Tupman, supra note 43, at 45.

140 Id. at 45; LUTTRELL, supra note 31, at 225.

141 See Luttrell, supra note 31, at 226; SChreuer et Al., Commentary, supra note 16, Art. 57, ๆ 22.

142 Tupman, supra note 43 , at 45.

$143 I d$. at 45 (based on this reasoning, the unchallenged arbitrators dismissed the Claimant's argument that party-appointed arbitrators should be subject to a more lenient standard of independence and impartiality). See also DAELE, supra note 51, 9 5-0o6. 


\subsection{Requirement of Reasonable Doubts under Vivendi and SGS}

The second arbitrator challenge under the ICSID Convention was made in Vivendi. ${ }^{144}$ Argentina challenged the president of the ad hoc Annulment Committee, Yves Fortier Q.C. One of the partners at his law firm had previously provided tax advice to the corporate predecessor of one of the Claimants (Vivendi Universal S.A.). Fortier was not personally involved in the tax advice, which was furthermore unrelated to the claim against Argentina.

The challenge was dismissed by Fortier's fellow committee members, who strongly criticized the Amco Asia decision, ${ }^{145}$ but who would not uphold a challenge that was based on "mere speculation or inference."146 For the request for disqualification to succeed, the entirety of the circumstances had to raise reasonable doubts ${ }^{147}$ about the committee member's impartiality.

The test applied by the committee members required the challenging party to establish, in a first step, the factual basis of its challenge, i.e. circumstances serious enough to put the independence or impartiality of the challenged arbitrator into question. In this first step, the reliance on mere speculation or inference was precluded. If the party succeeded at proving the factual basis of its challenge, however, inferences based on these facts were allowed in the second step. Namely, if the proven facts were to cast clear and reasonable doubt on the appearance of independence and impartiality or cause a reasonable apprehension of a "real risk" of bias, the challenge would be upheld. ${ }^{148}$

Because the decision commingles different standards of independence and impartiality which contradict each other, it is sometimes held to be of limited usefulness. ${ }^{149}$ The commonalities of the standards mentioned by the Annulment Committee members, however, deserve more attention than nomenclature: Under none of the invoked standards does the challenging party need to prove the challenged arbitrator's actual bias. Inferences from the established facts are allowed, and have an influence on the success of the challenge. This interpretation of the manifest lack requirement considerably lowers the threshold for arbitrator challenges, and approximates it to the threshold applied in most other dispute resolution mechanisms. ${ }^{150}$

\footnotetext{
144 Supra note 138.

145 Vivendi, 122.

146 Vivendi, $\mathbf{9} 25$.

147 Vivendi, I 25; Fry and Stampalija, supra note 31, at 211.

148 Vivendi, 925 ; Luttrell, supra note 31, at 228; SChreuer Et Al., Commentary, supra note 16 , Art. 57, I 25 .

149 LutTRELL, supra note 31, at 229.

$15^{0}$ See infra Chapter 3 .
} 
The challenge decision in $s G s^{151}$ is even clearer in this respect: It states that an inference of manifest bias is sufficient as a basis for disqualification, as long as it is anchored to facts - as opposed to speculations or inferences established by the challenging party. ${ }^{152}$ Furthermore, the facts must only reasonably ${ }^{153}$ - not compellingly - generate the inference that "clearly, the person challenged is not to be relied upon for independent judgment, or that a readily apparent and reasonable doubt as to that person's reliability for independent judgment has arisen." 154 The challenging party does not need to prove actual bias under this standard. A real risk or reasonable apprehension of bias is sufficient. ${ }^{155}$

Summing up, the early case law on arbitrator challenges does not provide a clear-cut answer to the question what distinguishes an ordinary lack of qualities from a manifest lack. The challenging party's burden of proof ranges from the need to prove actual bias to having to prove facts from which bias can reasonably be inferred, or which justify doubts about the arbitrator's independence and impartiality. In light of the wide-spread criticism of Amco Asia, ${ }^{156}$ and the tendency toward a more lenient threshold in Vivendi and $s G s$, one might expect that a lower threshold was forthwith applied to arbitrator challenges. The analysis of the challenge decisions rendered in the wake of Amco Asia, Vivendi and $s G s$, however, indicates that this is not the case.

151 SGS Société Générale de Surveillance S.A. v. Islamic Republic of Pakistan (sGS), ICSID Case No. ARB/o1/13, Decision on Claimant's Proposal to Disqualify Arbitrator (Dec. 19, 2002). Claimant challenged the Respondent-appointed arbitrator, Mr. J. Christopher Thomas. In several unrelated prior investor-State arbitration proceedings, Mr. Thomas and counsel for Respondent (Mr. Jan Paulsson) had been involved simultaneously, in reversed roles. In one case, in which Mr. Thomas represented Respondent, and Mr. Paulsson presided over the tribunal, all claims against the Respondent were dismissed. Claimant argued that Mr. Thomas might feel indebted to Mr. Paulsson and therefore not approach the case with the required open-mindedness.

152 LutTRELL, supra note 31, at 230 (arguing that the real contribution of $s G s$ was the determination of an objective, "reasonable person" vantage point. Luttrell does not pay further attention to the facts-inference test established in $s G s$, claiming that it conflicts with Amco Asia and Vivendi.).

$153 S G S$, ๆ 21 ("There must ... be a clear and reasonable relationship between the constituent facts and the constituent inference they generate.").

154 Id. $₫ 21$.

155 Schreuer et Al., Commentary, supra note 16, Art. 57, ๆ 29.

156 See, e.g., Tupman, supra note 43, at 51 ("[T]he tribunal imposed a standard that would tolerate virtually any prior business or professional relationship."). 


\subsection{Inconsistency of the Disqualification Threshold in Subsequent Decisions}

The challenge decisions rendered following $s G s$ can be subdivided into three categories, pursuant to the burden of proof imposed on the challenging party. The first group of cases follows in the footsteps of Amco Asia and requires the challenging party to furnish strict proof of the arbitrator's actual lack of independence and impartiality. The second category of cases applies a more lenient threshold, as previously set out in Vivendi and $s G s$ : An arbitrator may be disqualified if the challenging party proves circumstances from which bias can reasonably be inferred, or which lead to justified doubts regarding the arbitrator's independence or impartiality. Finally, in a third group of cases, the standards applied in Amco Asia and in Vivendi are both referred to, and the challenges are dismissed.

A Challenge Decisions Applying the Amco Asia Standard Suez II ${ }^{157}$ merely hints at Amco Asia by stating that the lack of independence must be "highly probable," and not just "possible."158 Apart from that, the decision mainly provides practical indicators for a case-by-case appraisal of connections between an arbitrator and a party, ${ }^{159}$ instead of abstractly defining the term "manifest lack." The significance of the reference to Amco Asia is therefore doubtful.

In $P I P,{ }^{160}$ the ICSID Chairman required the challenging party to establish the facts on which its request was based, and to demonstrate that those facts

157 Suez, Sociedad General de Aguas de Barcelona S.A. and Interagua Servicios Integrales de Agua S.A. v. Argentine Republic (ICSID Case No. ARB/o3/17), Suez, Sociedad General de Aguas de Barcelona S.A. and Vivendi Universal S.A. v. Argentine Republic (ICsid Case No. ARB/03/19), AWg Group v. Argentine Republic (Uncitral) (Suez II), Decision on a Second Proposal for the Disqualification of a Member of the Arbitral Tribunal (May 12, 2008). In Suez II, Argentina challenged Professor Kaufmann-Kohler based on her position as a director of UBS. UBS was a shareholder of two of the Claimants and made recommendations with respect to investments in the sector in which they operated. As a director of uBs, Professor Kaufmann-Kohler received a portion of her compensation in uBs stock. Argentina argued that this would cause her to have a personal (economic) interest in the outcome of the proceeding, and prevent her from adjudicating the case independently and impartially.

158 LUtTRELL, supra note 31, at 235.

159 Suez II, I 35. See also LutTRELL, supra note 31, at 235.

160 Participaciones Inversiones Portuarias SARL v. Gabonese Republic (PIP), ICSID Case No. ARB/08/17, Decision on Proposal for Disqualification of an Arbitrator (Nov. 12, 2009). 
prove a manifest lack of impartiality. ${ }^{161}$ Apart from this rather general reference to the Amco Asia standard, the ICsID Chairman also referred to Vivendi and $s G s,{ }^{162}$ but did not include the parts of the Vivendi standard which depart from Amco Asia in his analysis. In particular, the ICSID Chairman did not as much as mention the terms "inference" or "reasonable doubts."

The unchallenged arbitrators dealing with the Tidewater ${ }^{163}$ challenge highlighted that the ICSID standard "differs from the 'justifiable doubts' test formulated in the IBA Guidelines," ${ }^{164}$ without however explaining wherein precisely said difference lies. In fact, their definition of a manifest lack - "if the facts or circumstances ... are of such gravity ... as to call into question the ability of the arbitrator to exercise independent and impartial judgment"165 - is reminiscent of the "justifiable doubts" standard. Later in the decision, however, the threshold appears to be higher, requiring that the circumstances "justify reaching the conclusion that Professor Stern manifestly lacked independence or impartiality."166 The request for disqualification was dismissed arguing ad maiorem minus: Since the challenge would not be upheld under the (inapplicable) IBA Guidelines, it was even less promising under the ICsID Convention. The unchallenged arbitrators thereby elegantly evaded taking a stand on the ICSID standard.

In $O P I C,{ }^{167}$ the challenging party was required to clearly and objectively "establish a manifest lack" of independence, and not just an appearance

Professor Ibrahim Fadlallah, appointed to the tribunal by Claimant, had previously chaired a tribunal in a proceeding against Gabon. Gabon had requested the annulment of the award, and the annulment proceeding was pending.

$161 \quad P I P$, II 23.

$162 \quad P I P$, ๆ 22.

163 Tidewater Investment SRL and Tidewater Caribe, C.A. v. Bolivarian Republic of Venezuela (Tidewater), ICsID Case No. ARB $/ 10 / 5$, Decision on the Proposal for the Disqualification of a Member of the Arbitral Tribunal (Dec. 23, 2010). Professor Brigitte Stern's disqualification was requested based on her repeat appointments by Venezuela and its counsel in four investor-State disputes.

164 Id. If 43 (referring to the гвA Guidelines on Conflicts of Interest in International Arbitration, approved on May 22, 2004 by the Council of the International Bar Association, hereinafter the IвA Guidelines).

165 Id. \ 40.

166 Id. ๆ 47. See also the reference to Suez II, \39.

167 OPIC Karimum Corporation v. Bolivarian Republic of Venezuela (OPIC), ICsID Case No. ARB/10/14, Decision on the Proposal to Disqualify Professor Philippe Sands (May 5, 2011). Professor Philippe Sands was challenged because of his repeat appointments by Venezuela and its counsel (Curtis, Mallet-Prevost, Colt \& Mosle LLP). His previous two appointments by Venezuela had however never materialized - they had in fact concerned 
thereof. ${ }^{168}$ In their examination of the Claimant's arguments, however, the unchallenged arbitrators explained that "multiple appointments of an arbitrator by a party or its counsel is [sic] a factor which ... may lead to the conclusion that it is manifest that the arbitrator cannot be relied upon to exercise independent judgment." 169 Such a conclusion would logically be an inference from the established facts (i.e. multiple appointments), an impression or appearance created thereby. The standard so starkly phrased in abstract terms is therefore mitigated in its differentiated application to the facts. Ultimately, the unchallenged arbitrators do not appear to expect a strict proof of the challenged arbitrator's state of mind.

In Universal Compression, ${ }^{170}$ the challenge of a majority of the tribunal triggered the competency of the ICSID Chairman, who dismissed the request applying the strict standard established in Amco Asia: The challenging party was expected to establish objective facts which would suggest that the arbitrators' independence or impartiality was manifestly impacted. ${ }^{171}$

The Amco Asia standard was further applied in ConocoPhillips I, where the unchallenged arbitrators required objective evidence of an obvious, evident and highly probable, not just possible lack of independence and impartiality. ${ }^{172}$

the same dispute, which was filed in several fora. The respective tribunals had either rejected their jurisdiction, or never been constituted to begin with.

168 Id. ๆी 44-45.

169 Id. $₫ 50$.

170 Universal Compression International Holdings, S.L.U. v. Bolivarian Republic of Venezuela (Universal Compression), ICSID Case No. ARB/10/9, Decision on the Proposal for the Disqualification of two Members of the Arbitral Tribunal (May 20, 2011). Claimant requested the disqualification of Professor Brigitte Stern based on her repeat appointments by Venezuela and its counsel (Curtis, Mallet-Prevost, Colt \& Mosle LLP) in four cases. Respondent challenged Professor Tawil, the Claimant-appointed arbitrator. Allegedly, Professor Tawil had entertained a professional relationship with counsel for Claimant (King \& Spalding LLP) for over ten years, acting as their co-counsel in at least three ICSID proceedings. One of King \& Spalding LLP's attorneys had been employed in Professor Tawil's law firm for four years, and had as such worked with him personally.

$171 \quad I d .972$ and 77.

172 ConocoPhillips Petrozuata B.V., ConocoPhillips Hamaca B.V. and ConocoPhillips Gulf of Paria B.V. v. Bolivarian Republic of Venezuela (ConocoPhillips I), ICSID Case No. ARB/07/30, Decision on the Proposal for the Disqualification of L. Yves Fortier, Q.C. (Feb. 27, 2012), I 56. ConocoPhillips I marks the beginning of a series of challenges of the Claimant-appointed arbitrator Yves Fortier, Q.C. by Venezuela. Mr. Fortier's law firm (Norton Rose LLP) was about to merge with Macleod Dixon LLP, the single most adverse law firm to Respondent's interests, whose case portfolio relied heavily on disputes against Venezuela (according to Respondent). As a reaction to Venezuela's request for 
In ConocoPhillips $I V,{ }^{173}$ the unchallenged arbitrators provided no explanations on the applicable standard, but dismissed the challenge because Venezuela had "not established that Mr. Fortier manifestly lacks the ability to act independently and impartially." The allegations on which Venezuela based its challenge would have to be established, and would have to "[give] rise to a manifest lack of independence and impartiality in this case."174 The requirement of proving a manifest lack of independence and impartiality is reminiscent of the Amco Asia standard, even if the term "strict proof" was not used.

In ConocoPhillips $V,{ }^{175}$ the unchallenged arbitrators specified that what mattered was whether "a reasonable third person, with knowledge of all the facts, would conclude, on an objective basis, that the arbitrator is manifestly lacking in the ability to act impartially."176 In their application of this standard

disqualification, Mr. Fortier announced that he would resign from Norton Rose LLP on the day before the merger. Until then, ethical screens would ensure his impartiality. Venezuela adhered to its request, arguing that neither ethical screens (which allegedly did not function), nor Mr. Fortier's resignation could rule out that he would be influenced by his former firm's interests in the dispute.

173 ConocoPhillips Petrozuata B.V., ConocoPhillips Hamaca B.V. and ConocoPhillips Gulf of Paria B.V. v. Bolivarian Republic of Venezuela (ConocoPhillips IV), ICsid Case No. ARB/07/30, Decision on the Proposal to Disqualify L. Yves Fortier, Q.C. (Dec. 15, 2015). Venezuela's fourth challenge of Yves Fortier, Q.C. was motivated by the arbitrator's ongoing relationship with Norton Rose LLP, specifically his continued use of members of Norton Rose as tribunal assistants. For example, Mr. Martin Valasek (a partner at Norton Rose LLP) served as an assistant to the Yukos tribunal, which was presided over by Mr. Fortier (Hulley Enterprises Limited (Cyprus) v. Russian Federation (PCA Case No. AA 226), Yukos Universal Limited (Isle of Man) v. Russian Federation (PCA Case No. AA 227), and Veteran Petroleum Limited (Cyprus) v. Russian Federation (PCA Case No. AA 228)). Allegedly, Valasek had even written the historic USD 50 billion award in lieu of the arbitrators. Respondent reiterated that the continued close professional relationship between Mr. Fortier and Norton Rose raised doubts about his independence and impartiality.

174 Id. 940.

175 ConocoPhillips Petrozuata B.V., ConocoPhillips Hamaca B.V. and ConocoPhillips Gulf of Paria B.V. v. Bolivarian Republic of Venezuela (ConocoPhillips V), ICsid Case No. ARB/07/30, Decision on the Proposal to Disqualify L. Yves Fortier, Q.C. (Mar. 15, 2016). Venezuela's fifth request for the disqualification of Yves Fortier, Q.C. was based on inaccuracies in his disclosure regarding the service of a Norton Rose lawyer as an assistant on a tribunal he chaired. These inaccuracies were argued to create "an impression of 'lesser ties to Norton Rose than actually existed"” (id. ๆ 25), and to thereby raise doubts regarding his independence and impartiality.

$176 \quad$ Id. $\uparrow 33$. 
to the specific facts at hand, ${ }^{177}$ the unchallenged arbitrators imposed a high threshold, which resembles the Amco Asia standard, rather than a reasonable doubts approach.

\section{B Challenge Decisions Applying the Vivendi Standard}

Although the terminology used in $E D F^{178}$ differs from Vivendi, the standard is the same: The lack of independence and impartiality must be easily perceptible, and the test is whether a reasonable observer would find it credible that the arbitrator's "independence would ... fluctuate" under the given circumstances. ${ }^{179}$ In other words, a reasonable third person would have reasonable or justifiable doubts regarding the arbitrator's reliability to exercise independent judgment. ${ }^{180}$

In Alpha Projektholding, ${ }^{181}$ the unchallenged members of the tribunal required Respondent to establish facts which would give rise to the inference that "clearly, the person challenged is not to be relied upon for independent judgment, or that a readily apparent and reasonable doubt as to that person's reliability for independent judgment has arisen from the facts established." 182

In Urbaser, ${ }^{183}$ Claimants requested Professor McLachlan's disqualification, based on his academic publications. The unchallenged co-arbitrators held that

$177 \quad$ Id. $\ 35$.

178 EDF International S.A., SAUR International S.A., Léon Participaciones Argentinas S.A. v. Argentine Republic $(E D F)$, ICSID Case No. ARB/o3/23, Challenge Decision Regarding Professor Gabrielle Kaufmann-Kohler (June 25, 2008). Argentina challenged Professor Kaufmann-Kohler based on her position as a director of uBs. uBs had recommended investments in the parent company of one of the Claimants and had a common interest in several companies with EDF. Argentina argued that since Professor Kaufmann-Kohler received a portion of her compensation in UBS stock, she had a personal (economic) interest in the outcome of the proceeding, which would prevent her from adjudicating the case independently and impartially.

179 Id. $\uparrow$ ๆ 65,68 and 74 .

$180 \quad$ Id. 964.

181 Alpha Projektholding GmbH v. Ukraine (Alpha Projektholding), ICSID Case No. ARB/o7/16, Decision on Respondent's Proposal to Disqualify Arbitrator Dr. Yoram Turbowicz (Mar. 19, 2010). The Ukraine requested the disqualification of Dr. Yoram Turbowicz (the Claimant-appointed arbitrator) because he had studied together with counsel for Claimant at Harvard Law School twenty years earlier. Allegedly, Dr. Turbowicz lacked any prior experience and expertise in transnational investment or commercial arbitration.

$182 \quad I d .937$ (referencing $s G s$ ).

183 Urbaser S.A. and Consorcio de Aguas Bilbao Bizkaia, Bilbao Bizkaia ur Partzuergoa v. Argentine Republic (Urbaser), ICsID Case No. ARB/o7/26, Decision on Claimant's Proposal to Disqualify Professor Campbell McLachlan, Arbitrator (Aug. 12, 2010). 
since everyone is embedded in a "moral, cultural, and professional" setting, unbiased decision-making was to be defined as the "ability to consider and evaluate the merits of each case without relying on factors having no relation to such merits." The reliance on irrelevant criteria, however, would not have to be proven by the challenging party - its "appearance ... from a reasonable and informed third person's point of view is sufficient to justify doubts about an arbitrator's independence or impartiality."184

In another case, Blue Bank, ${ }^{185}$ the test applied was whether "a third party would find an evident or obvious appearance of lack of impartiality on a reasonable evaluation of the facts." ${ }^{186}$ According to the ICSID Chairman, the cumulation of several facts resulted in a manifest appearance of a lack of impartiality. ${ }^{187}$

The request for the disqualification of two arbitrators in Repsol ${ }^{188}$ was denied in application of the Vivendi standard. The ICSID Chairman clearly stated

$184 \quad I d .943$.

185 Blue Bank International \& Trust (Barbados) Ltd. v. Bolivarian Republic of Venezuela (Blue Bank), ICSID Case No. ARB/12/20, Decision on the Parties' Proposal to Disqualify a Majority of the Tribunal (Nov. 12, 2013). Respondent requested the disqualification of José María Alonso, the arbitrator appointed by Claimant, and a partner at Baker \& McKenzie Madrid. While Mr. Alonso served as an arbitrator in Blue Bank, attorneys in the New York and Caracas offices of his firm advised Claimant on an ongoing unrelated proceeding against the same Respondent, which concerned similar issues. In his function as an arbitrator, Mr. Alonso would have been in a position to decide issues relevant to the parallel proceeding in which his colleagues were involved. Mr. Alonso was also a member on Baker \& McKenzie's international arbitration steering committee, and his remuneration was partially dependent on the results achieved by firms other than Baker \& McKenzie Madrid.

186 Id. ๆ 69.

187 Id. ๆ $67-69$.

188 Repsol, S.A. and Repsol Butano, S.A. v. Argentine Republic (Repsol), ICSID Case No. $\mathrm{ARB} / 12 / 38$, Decision on the Proposal for the Disqualification of a Majority of the Tribunal (Dec. 13, 2013). Respondent requested the disqualification of both Dr. Claus von Wobeser (the chairman of the tribunal) and Professor Francisco Orrego Vicuña (the Claimantappointed arbitrator). Dr. von Wobeser had collaborated with counsel for Claimant (Freshfields Bruckhaus Deringer LLP) as co-counsel in a commercial arbitration nine years earlier, and he was appointed in one other ICSID proceeding against Argentina, which allegedly concerned the same emergency measures as those at issue in Repsol. Professor Orrego Vicuña was challenged based on his repeat appointments against Argentina. Argentina claimed that the annulment of three ICSID awards previously rendered in its detriment by tribunals presided by Professor Orrego Vicuña caused him to bear a manifest animosity against Argentina. Furthermore, Repsol would concern the same emergency measures as the previous three cases, and the same legal questions (notably 
that no strict evidence of an actual dependence or predisposition is required, but that it is sufficient to establish an appearance of such a state of mind, from the perspective of a reasonable third person. ${ }^{189}$ The term "manifest" was held to mean obvious or evident and to refer to the facility with which the alleged lack of qualities could be perceived. . $^{190}$

Using exactly the same terminology to describe the ICSID challenge standard, the ICSID Chairman upheld the challenge in Burlington ${ }^{191}$ on the same day.

Caratube $^{192}$ marks the first (published) ICsID challenge in which an arbitrator was disqualified by his co-arbitrators. ${ }^{193}$ The unchallenged arbitrators went to great lengths to emphasize that they did not doubt Mr. Boesch's

the defense of necessity). Professor Orrego Vicuña's attempts to justify his position in the annulled cases in academic writing were argued to be further proof of his prejudice.

189 Id. ๆ 71-72 ("Los Artículos 57 y $5^{8}$ del Convenio del CiADi no requieren evidencia de dependencia o predisposición real, sino que es suficiente con establecer la apariencia de dependencia o predisposición. ... El estándar legal aplicable es un 'estándar objetivo, basado en una evaluación razonable de la prueba, realizada por un tercero."”).

190 Id. 973 (“[El] adjetivo 'manifiesta'... significa 'obvia o evidente' y ... se refiere a la 'facilidad con la que la supuesta falta de cualidades puede percibirse.").

191 Burlington Resources, Inc. v. Republic of Ecuador (Burlington), ICsid Case No. ARB/08/5, Decision on the Proposal for Disqualification of Professor Francisco Orrego Vicuña (Dec. 13, 2013), ๆๆ 66-68. Ecuador challenged Professor Francisco Orrega Vicuña because of his repeat appointments by Freshfields in seven prior ICsID proceedings, and his "blatant lack of impartiality to the detriment of Ecuador in the course of the arbitration." Professor Orrega Vicuña reacted to the challenge by reprimanding counsel for Respondent (Dechert LLP): He claimed that in one of its submissions, Dechert LLP had disclosed information from another proceeding which was confidential, and that accordingly, not his own behavior, but that of counsel for Respondent posed "the real ethical question." This criticism resulted in his disqualification.

192 Caratube International Oil Company LLP and Devincci Salah Hourani v. Republic of Kazakhstan (Caratube), ICSID Case No. ARB/13/13, Decision on the Proposal for Disqualification of Bruno Boesch (Mar. 20, 2014). Mr. Boesch was appointed by Kazakhstan in a parallel proceeding, in which the facts and the law were essentially identical, and the parties relied on the same witnesses, experts and evidence. Counsel for Respondent (Curtis, Mallet-Prevost, Colt \& Mosle LLP) had appointed Mr. Boesch in at least two additional cases, although he allegedly lacked prior experience with ICSID arbitration.

193 Chiara Giorgetti, Caratube v. Kazakhstan: For the First Time Two ICsID Arbitrators Uphold Disqualification of Third Arbitrator, American Society for International Law INSIGHTS (Sept. 29, 2014), http://www.asil.org/insights/volume/18/issue/22/caratubev-kazakhstan-first-time-two-icsid-arbitrators-uphold [hereinafter Giorgetti, Caratube v. Kazakhstan]. 
assurances regarding his objectivity and open-mindedness, and that his "actual independence and ... impartiality, his state of mind, his ethical or moral strength" were undisputed. ${ }^{194}$ They explained that they did not base their decision on his actual impartiality, but on its perception from an objective point of view: ${ }^{195}$ The decisive question was whether a reasonable third party would find that there is an evident or obvious appearance of lack of impartiality or independence, ${ }^{196}$ a risk of unconscious bias. ${ }^{197}$ His appointment in closely related cases, they held, would create an "evident or obvious appearance of lack of impartiality." ${ }^{198}$

In ConocoPhillips $I I^{199}$ and ConocoPhillips $I I I^{200}$ the ICSID Chairman applied the Vivendi standard, echoing the terminology of Repsol and Burlington.

The same standard was applied in Ickale: The unchallenged arbitrators reiterated that proof of actual dependence or bias was not required, but that the challenging party had to establish facts which indicate a lack of independence

\footnotetext{
194 Caratube, ๆ 64.

195 Id. \ 75.

196 Id. 964 and 75.

$197 I d$ ๆ 89 (“[T] here is an evident or obvious appearance of lack of impartiality as this concept is understood without any moral appraisal: a reasonable and informed third party observer would hold that Mr. Boesch, even unwittingly, may make a determination in favor of one or as a matter of fact the other party that could be based on such external knowledge.").

198 Id. ๆๆ 89-91.

199 ConocoPhillips Petrozuata B.V., ConocoPhillips Hamaca B.V. and ConocoPhillips Gulf of Paria B.V. v. Bolivarian Republic of Venezuela (ConocoPhillips II), ICSID Case No. ARB/07/3o, Decision on the Proposal to Disqualify a Majority of the Tribunal (May 5, 2014), ๆ 47 and $5^{2-53}$. Venezuela based its request for disqualification on the refusal of Judge Keith and Yves Fortier Q.C. to reconsider their decision on jurisdiction, which was allegedly premised on improper inferences from falsely represented facts.

200 ConocoPhillips Petrozuata B.V., ConocoPhillips Hamaca B.V. and ConocoPhillips Gulf of Paria B.V. v. Bolivarian Republic of Venezuela (ConocoPhillips III), ICSID Case No. $\mathrm{ARB} / \mathrm{o}_{7} / 3^{0}$, Decision on the Proposal to Disqualify a Majority of the Tribunal (July 1, 2015), ๆ 83. Venezuela's third challenge of Yves Fortier, Q.C. was motivated by the arbitrator's ongoing relationship with Norton Rose LLP, specifically his continued use of members of Norton Rose as tribunal assistants. Respondent claimed that Mr. Martin Valasek (a partner at Norton Rose LLP) served as an assistant to the Yukos tribunal (Hulley Enterprises Limited (Cyprus) v. Russian Federation (PCA Case No. AA 226), Yukos Universal Limited (Isle of Man) v. Russian Federation (PCA Case No. AA 227), and Veteran Petroleum Limited (Cyprus) v. Russian Federation (PCA Case No. AA 228)), which was chaired by Mr. Fortier, and that Valasek had even written the award in said proceeding in lieu of the arbitrators.
} 
and impartiality which "can be perceived on the face of the evidence submitted."201

\section{Challenge Decisions Referring to Both Standards}

In this third category of cases, the unchallenged arbitrators referred to both the standard applied in Amco Asia as well as the standard applied in Vivendi, and dismissed the challenges. The significance of these decisions for the ICSID case law on arbitrator challenges is debatable. In some of the cases, previously defined standards are reproduced only in fragments, thereby effectively elevating the threshold for a successful challenge. In other cases, inherently contradictory terms which were previously used in the context of dissimilar standards are combined, creating an opaque and ambiguous description of the requirements for a successful challenge. Instead of clarifying the applicable standard and making policy choices transparent, these decisions add to the confusion about the pertinent threshold for arbitrator challenges and obscure the reasons for the dismissal of the challenges.

In Suez I, ${ }^{202}$ the unchallenged arbitrators held that a manifest lack of independence or impartiality had to be proven by objective evidence, and that the mere belief of such a lack was insufficient. ${ }^{203}$ Citing the first leg of the test applied in $s G S$, requiring the challenging party to establish facts which could give rise to the inference that "clearly, the person challenged is not to be relied upon for independent judgment,"204 the unchallenged arbitrators concluded that the "mere appearance of partiality was not a sufficient ground."205 Had they, however, not cut off the $s G s$ test in mid-sentence, its irreconcilable conflict with Amco Asia would have been obvious: According to the second

201 İçkale İnşaat Limited Şirketi v. Turkmenistan (Ickale), ICSıD Case No. ARB/10/24, Decision on the Proposal to Disqualify Philippe Sands (July 11, 2014), I 117. Professor Philippe Sands was challenged because of his repeat appointments by Turkmenistan and its counsel (Curtis, Mallet-Prevost, Colt \& Mosle LLP). Turkmenistan had appointed him in two other cases; counsel for Respondent had appointed him in three other proceedings.

202 Suez, Sociedad General de Aguas de Barcelona S.A. and Interagua Servicios Integrales de Agua S.A. v. Argentine Republic, ICSID Case No. ARB/o3/17, Suez, Sociedad General de Aguas de Barcelona S.A. and Vivendi Universal S.A. v. Argentine Republic, Icsid Case No. ARB/o3/19, AWG Group v. Argentine Republic (UnCitral) (Suez I), Decision on the Proposal for the Disqualification of a Member of the Arbitral Tribunal (Oct. 22, 2007). Argentina requested the disqualification of Professor Gabrielle Kaufmann-Kohler based no her involvement in the allegedly flawed decision in Vivendi (supra note 138).

203 Suez I, ๆ 40.

$204 s G s, \boldsymbol{\Upsilon} 21$.

205 Suez I, ๆ 9 40-41 (corresponding with Amco Asia). 
leg of the $s G s$ test, the inference of "a readily apparent and reasonable doubt as to that person's reliability for independent judgment" is sufficient for the challenge to succeed. ${ }^{206}$ Hence, in contrast to Amco Asia, the appearance of bias may well be sufficient for a disqualification under $s G s$. It is regrettable that the unchallenged arbitrators did not seize the opportunity to address this disaccord and to provide a transparent explanation of their preference for the Amco Asia standard. By not taking a stand, and instead commingling the different standards in the decision, they introduced unnecessary inconsistencies and contradictions into the Suez I decision, adding confusion to the arbitrator challenge jargon. For example, the requirement of "objective evidence" which directly proves a manifest lack of independence or impartiality ${ }^{207}$ excludes the admissibility of the inference of a manifest lack, ${ }^{208}$ contrary to the unchallenged arbitrators' explicit statements in the same decision. ${ }^{209}$ The confusion caused by Suez I is all the more regrettable considering that the unchallenged arbitrators' statements are obiter dicta - the request was dismissed because it was belated. ${ }^{210}$

The unchallenged arbitrators in Electrabel ${ }^{211}$ made no reference to Amco Asia or Vivendi, but instead derived an intermediate standard of review from the interpretation of the term "manifest" in the context of Article 52 para. 2 (b) ICSID Convention. Thereunder, "manifest" means "self-evident, clear, plain on its face or even certain, rather than the product of elaborate interpretations one way or another or susceptible of argument one way or another or being necessary to engage in elaborate analyses." 212 It refers to "the ease with which it is perceived" and "the cognitive process that makes it apparent."213 This explanation does not use the terms "strict proof," "doubts" or "appearance," which

\footnotetext{
$206 s G s, \boldsymbol{\Upsilon} 21$.

207 Suez I, ๆ 40.

208 See LUtTRELL, supra note 31, at 232.

209 Suez I, I 30 (implying that the actual existence of a manifest lack must not be proven, since "[i]ndependence and impartiality are states of mind [which] can only be inferred from conduct.") and $₫ 40$ (citing $s G s$ ).

210 Id. ๆ 26; see also LutTRE LL, supra note 31, at 232.

211 Electrabel S.A. v. Republic of Hungary (Electrabel), ICSID Case No. ARB/o7/19, Decision on the Claimant's Proposal to Disqualify a Member of the Tribunal (Feb. 25, 2008). Professor Brigitte Stern was challenged because of her parallel appointment by Hungary and counsel for Respondent (Arnold \& Porter LLP) in another proceeding, which concerned the same agreements, the same government action, and the same treaty.

$212 I d .936$ (internal quotation marks omitted).

213 Id. 936.
} 
usually signal the threshold referred to. As a consequence, it leaves a lot of room for speculation.

In Nations Energy, ${ }^{214}$ Claimant requested the disqualification of one of the ad hoc Committee members, based on his past professional relationship with counsel for Respondent. ${ }^{215}$ The unchallenged ad hoc Committee members dismissed the request in application of the Amco Asia standard, requiring objective proof of a manifest lack of independence or impartiality, ${ }^{216}$ i.e. the proof of facts indicating an evident and highly probable, not just possible, lack of the arbitrator's reliability for independent and impartial judgment. ${ }^{217}$ They did, however, include a passage from Vivendi for good measure, stating that the entirety of the circumstances had to be taken into account to determine whether the circumstances justified reasonable doubts regarding the arbitrator's ability to render a free and independent decision. ${ }^{218}$

The challenge decision in Abaclat $I^{219}$ was based on a recommendation by the Secretary-General of the Permanent Court of Arbitration (PCA). ${ }^{220}$ Respondent argued that several procedural decisions of the majority of the tribunal were so manifestly flawed that they could only be explained by a lack of

214 Nations Energy, Inc. and others v. Republic of Panama (Nations Energy), ICsid Case No. ARB/o6/19, Decision on a Proposal to Disqualify Dr. Stanimir Alexandrov (Sept. 7, 2011).

215 One of Respondent's attorneys had previously been employed by Sidley Austin LLP, where Dr. Alexandrov allegedly supervised him in his work on several ICsID proceedings.

216 Nations Energy, I 56 ("carencia manifiesta de las cualidades exigidas [que] debe ser demostrada con pruebas objetivas”) and \ 68 („información ... que objetivamente demuestre o sugiera que la existencia de dicha relación puede influenciar el juicio del Dr. Alexandrov.").

217 Id. ๆ 65 ("probar los hechos que hagan evidente y sumamente probable, y no solamente possible, que [el árbitro] sea una persona en quien no se puede confiar para pronunciarse en forma independiente e imparcial.").

$218 I d$. \ 67 (“[T] odas las circunstancias deben tomarse en cuenta para poder determinar $s i$ la relación es sufisamente significativa para justificar la presencia de dudas razonables en cuanto a la capacidad del árbitro o miembro de alcanzar una decisión libre e independientemente [sic].").

219 Abaclat and others v. Argentine Republic (Abaclat I), ICSID Case No. ARB/o7/5, Rejection of Request for Disqualification of Professor Pierre Tercier and Professor Albert Jan van den Berg (Dec. 21, 2011).

220 Abaclat and others v. Argentine Republic, ICsid Case No. ARB/07/5, Recommendation on the Respondent's Proposal for the Disqualification of Professor Pierre Tercier and Professor Albert Jan van den Berg, PCA Case No. IR 2011/1 (Dec. 19, 2011). The majority of the tribunal was challenged and Respondent requested a recommendation from the Secretary-General of the PCA, which the ICSID Chairman granted. 
independence and impartiality. ${ }^{221}$ According to the Secretary-General of the PCA, adverse decisions alone could never be considered a sufficient indication of bias, even if they were wrong in fact or in law. ${ }^{222}$ In such cases, the challenging party would always have to prove that the arbitrator was in fact influenced by irrelevant factors, or establish additional facts from which a lack of independence or impartiality could be inferred. ${ }^{223}$ In other words, if the party based its challenge on the wrongfulness of the award, or procedural flaws, the Amco Asia standard would apply, requiring strict proof of bias. ${ }^{224}$ In the alternative, the challenge could be based on other "objective facts," from which a lack of independence or impartiality could reasonably be inferred, as stipulated in Vivendi. ${ }^{225}$

In Getma, ${ }^{226}$ Guinea requested the disqualification of the Claimantappointed arbitrator, whose brother simultaneously acted as an arbitrator in a proceeding involving the same Claimant and concerning the same facts. These circumstances were obviously considered delicate: The unchallenged arbitrators could not agree on the request, prompting the ICSID Chairman to deal with the challenge. As in Abaclat $I$, the request was dismissed, referencing both Amco Asia and Vivendi. The ICSID Chairman required Guinea to establish facts which would establish a manifest lack of independence ${ }^{227}$ and highlighted that mere speculation, presumption, belief, opinion or interpretation were insufficient. $^{228}$ The Respondent's inference of bias (or an apprehension thereof) from the involvement of the challenged arbitrator's brother in a parallel proceeding was dismissed as speculative. While the ICsID Chairman did not

\footnotetext{
221 Abaclat $\mathrm{I}, \mathbf{9} 72$.

222 Id. ๆ $94-65$ and 84. Understandably, the admission of wrongful decisions as a basis for arbitrator challenges would turn ICSID Convention art. 57 into an extension of the grounds for annulment. Any claim of manifest wrongness of a decision would have to be examined as to its severity. This would open the door for undesirable delaying tactics. On the other hand, it is inherent in the concept of bias that it occurs in the decision-maker's mind. The challenging party is hardly ever able to adduce additional facts to prove its existence.

223 Id. ๆ $156-157$.

224 Id. 150 (requiring the challenging party to "prove not only facts indicating the lack of independence, but also that the lack is 'manifest' or highly probable, not just possible.").

225 Id. 1 ๆ 53 and 63.

226 Getma International and others v. Republic of Guinea (Getma), ICsID Case No. ARB/11/29, Decision on the Proposal for Disqualification of Arbitrator Bernardo M. Cremades (June $28,2012)$

$227 \quad I d .958$.

228 Id. $\uparrow 60$.
} 
accept the inference of a lack of independence from the brothers' family ties, it appears that he would have accepted such an inference based on a different factual basis, in accordance with the Vivendi standard. ${ }^{229}$

In Saint-Gobain, ${ }^{230}$ the unchallenged arbitrators explicitly stated that there is "no unequivocal answer" to the question when a lack of independence and impartiality becomes manifest. ${ }^{231}$ However, they held that since Claimant failed to present facts that would cast reasonable doubts on the challenged arbitrator's independence and impartiality, ad maiorem minus, the established facts did not indicate a manifest (i.e. obvious and highly probable) lack of such qualities. ${ }^{232}$ The request would therefore have to be dismissed irrespective of the interpretation of the terms "manifest lack."

In Abaclat II, ${ }^{233}$ the ICSID Chairman unambiguously used the terms associated with Vivendi to describe the applicable challenge standard. ${ }^{234}$ In his application of that standard to the facts, however, he slipped back into the mindset of Amco Asia, stating that the established circumstances "do not prove a manifest lack of impartiality." 235 Whether they would have created the requisite appearance of bias remains unanswered.

A strict intermediate standard was applied by the unchallenged arbitrators in Total. ${ }^{236}$ They referenced several challenge decisions, most of which had

$229 I d$. $ๆ$ 6 $68-72$.

230 Saint-Gobain Performance Plastics Europe v. Bolivarian Republic of Venezuela (SaintGobain), ICSID Case No. ARB/12/13, Decision on Claimant's Proposal to Disqualify an Arbitrator (Feb. 27, 2013). Claimant requested the disqualification of Gabriel Bottini (the arbitrator appointed by Venezuela). In his previous function as National Director of International Matters and Disputes for the Office of the Attorney General of Argentina, Bottini had allegedly defended Argentina against claims very similar to the ones at hand. Furthermore, Bottini had been under direct supervision of Mr. Osvaldo Guglielmino, who now represented Venezuela in a parallel proceeding. The simultaneous involvement of the former colleagues in parallel proceedings was claimed to raise doubts regarding Mr. Bottini's independence and impartiality.

231 Id. ๆฯ 58-59 (referencing Amco Asia and Vivendi).

$232 \quad$ Id. 978.

233 Abaclat and others v. Argentine Republic (Abaclat II), ICSID Case No. ARB/07/5, Decision on the Proposal to Disqualify a Majority of the Tribunal (Feb. 4, 2014). Argentina challenged Pierre Tercier and Albert Jan van den Berg based on procedural decisions which it perceived to be unfair, and an indicator of their predisposition to its detriment.

234 Id. $\uparrow 91$ and $76-77$.

235 Id. ๆ 81.

236 Total S.A. v. Argentine Republic (Total), ICSID Case No. ARB/o4/o1, Decision on the Proposal to Disqualify Teresa Cheng (Aug. 26, 2015). Respondent challenged Teresa Cheng based on her connections to counsel for Claimant (Freshfields). Ms. Cheng had given 
applied the Vivendi standard, but avoided the terms "doubts" or "appearance." Highlighting that the standard of review under the ICsID Convention is strict and relatively high, they required the challenging party to prove facts which, if assessed by a reasonable third person in the light of the available evidence, would lead to the inference that the challenged arbitrator obviously cannot exercise his or her function independently. ${ }^{237}$ This is very different from proving that the facts give rise to justifiable doubts as to the arbitrator's independence and impartiality, or that they cause an appearance of bias. ${ }^{238}$

In ConocoPhilipps VI, ${ }^{239}$ the unchallenged arbitrators seemed to relinquish the strict proof of bias required in two of their previous disqualification decisions. ${ }^{240}$ They stated that "[a]rticles 57 and 14(1) of the ICSID Convention do not require proof of actual dependence or bias; rather, it is sufficient to establish the appearance of dependence or bias."241 Their seemingly unequivocal support for an appearance-based standard, however, stands in stark contrast to the requirement - set up in the same decision - that a reasonable third person must not only conclude that the arbitrator appears biased, but must conclude "that the challenged arbitrator is manifestly lacking in the ability to act impartially."242

legal advice and acted as a legal counsel for clients of Freshfields in two isolated instances, had acted as a Claimant-appointed arbitrator in a commercial arbitration against a party represented by Freshfields, and her son had completed a summer internship in the Paris office of the law firm.

237 Id. ๆ 105 ("La parte que recusa debe ... demostrar (a) los hechos que dan lugar a la recusación; y (b) que tales hechos, valorados razonablemente por un tercero a la luz de la evidencia disponible, tienen un carácter, naturaleza o entidad tales que puedan dar lugar a inferir que es manifiesto, que es obvio, que la persona recusada no puede ejercer un juicio independiente en el proceso particular en el que se presenta la recusación.").

238 See Tom Jones, Cheng survives first of challenges over Freshfields links, Global Arbitration Review (Sept. 3, 2015), http://globalarbitrationreview.com/news/article/34108/ cheng-survives-first-challenges-freshfields-links/.

239 ConocoPhillips Petrozuata B.V., ConocoPhillips Hamaca B.V. and ConocoPhillips Gulf of Paria B.V. v. Bolivarian Republic of Venezuela (ConocoPhillips VI), ICsid Case No. ARB/07/30, Decision on the Proposal to Disqualify L. Yves Fortier, Q.C. (July 26, 2016). In its sixth proposal for disqualification, Venezuela substantiated its allegation of Mr. Fortier's continued involvement with Norton Rose LLP by showing that his secretaries received insurance and other benefits from an entity set up by Norton Rose LLP (Services OR LP/SEC). Furthermore, Venezuela produced the LinkedIn profile of Mr. Fortier's secretary (Myriam Ntashamaje), according to which she worked for Norton Rose LLP.

240 ConocoPhillips IV and $v$.

241 ConocoPhillips VI, $\uparrow 12 \mathrm{12a}$.

242 ConocoPhillips VI, $\uparrow 12 \mathrm{~b}$. 
Finally, the unchallenged arbitrators in Favianca $I I^{243}$ and $I I I^{244}$ understood "manifest" to refer to the ease with which the alleged lack of qualities can be perceived. Similarly to the decision in Electrabel, they held that the lack of independence or impartiality must be evident and obvious for an objective third person. While the unchallenged arbitrators avoided the terms "strict proof," "doubts" or "appearance," they cited several decisions, which applied both the Amco Asia and (predominantly) the Vivendi standard. ${ }^{245}$ It is therefore unclear which one of those thresholds was considered pertinent.

\subsection{Conclusion}

This overview of the threshold applied in past challenge decisions allows for two conclusions.

First, a uniform interpretation of the manifest lack requirement provided for in Article 57 ICSID Convention has still not crystallized. This is remarkable, considering that more than thirty-four years have passed since the first ICSID challenge decision. Between 2013 and 2015, a series of eight decisions ${ }^{246}$ seemed to signal a more consistent application of the reasonable doubts threshold established in Vivendi; in particular, six disqualification decisions

243 Fábrica de Vidrios Los Andes, C.A. and Owens-Illinois de Venezuela, C.A. v. Bolivarian Republic of Venezuela (Favianca II), ICSID Case No. ARB/12/21, Decision on the Proposal to Disqualify L. Yves Fortier, Q.C. (Mar. 28, 2016). The challenge in Favianca II was based on arguments similar to those in ConocoPhillips $v$. The formal engagement by Mr. Fortier of a Norton Rose lawyer (Alison Fitzgerald) as tribunal assistant, after his resignation from Norton Rose LLP, and despite his assurances that he would sever all ties with the firm upon his resignation, was claimed to raise doubts as to his independence and impartiality. In Respondent's view, Mr. Fortier's inaccurate disclosure in this context further exacerbated such doubts.

244 Fábrica de Vidrios Los Andes, C.A. and Owens-Illinois de Venezuela, C.A. v. Bolivarian Republic of Venezuela (Favianca III), ICSID Case No. ARB/12/21, Decision on the Proposal to Disqualify L. Yves Fortier, Q.C. (Sept. 12, 2016). The facts underlying the challenge in Favianca III are the same as those invoked in ConocoPhillips VI. Respondent showed that Mr. Fortier's secretaries receive insurance and other benefits from an entity set up by Norton Rose LLP (Services OR LP/SEC) for the purpose of providing it with staff and administrative support services, and that one of his secretaries (Myriam Ntashamaje), according to her LinkedIn profile, is employed by Norton Rose LLP.

245 Favianca II, note 10; Favianca III, \4 45.

246 Blue Bank, Burlington, Repsol, Abaclat II, Caratube, ConocoPhillips II, Ickale, and ConocoPhillips III. Abaclat II appears to ultimately have been dismissed based on a standard reminiscent of Amco Asia (see supra Part 1.3 C.); since the ICSID Chairman only referenced the Vivendi standard, however, it is herein counted as one of the eight cases applying said standard. 
penned by the ICsID Chairman described the relevant threshold in unusually standardized and clear language. The most recent disqualification decisions, however, have put an end to (or interrupted) this sequence. ${ }^{247}$ At this time, it is uncertain which stance future disqualification decisions will take, and the burden of proof which will be imposed on challenging parties is unpredictable. ${ }^{248}$

The described inconsistency can only be explained by the lack of a formal rule of binding precedent in arbitration. ${ }^{249}$ Arbitrators appear to be so used to deciding individual disputes without having to situate their considerations in a system of existing case law that even when deciding challenges, they do not feel bound by previous disqualification decisions and the threshold established therein. This is evidenced by the decisions rendered in the wake of Vivendi and $s G s$, of which several applied the older Amco Asia standard, without justifying their departure from Vivendi and $s G s$. The recent divergence from the Vivendi standard in Total, ConocoPhillips IV, V and VI, and in Favianca II and $I I I$ is even more striking. The reasonable doubts standard had been

247 Total, ConocoPhillips IV, V and VI, and Favianca II and III. It is worth highlighting, however, that five of these decisions concerned the same arbitrator, and that the challenging parties based their requests for disqualification on the same arguments. Thus, the weight to be given to each individual disqualification decision is questionable.

248 See also DAELE, supra note 51, 9 5-004. Contra Kinnear and Nitschke, supra note 13, at 60 ("With the increased number of challenges and decisions on challenges in investment arbitration, the applicable standards and outcomes are becoming increasingly predictable."); Rubins and Lauterburg, supra note 32 , at 161 (“To justify the removal of an arbitrator, the petitioner's doubts must be justifiable on some objective basis, reasonable by the standard of a fair minded, rational, objective observer."); LUTTRELL, supra note 31, at 225, 242; Fry and Stampalija, supra note 31, at 248, 257 (arguing that the jurisprudence is becoming more stable, but heading in a direction opposed to modern arbitration rules); ReEd, Paulsson, AND Blackaby, supra note 13, at 134; Markert, supra note 21, at 224 (requiring strict proof of dependence or bias).

249 Caron, Investor State Arbitration, supra note 23, at 516-517; Rubins and Lauterburg, supra note 32, at 164; Howard Mann, The Emperor's Clothes Come Off: A Comment on Republic of Ghana v. Telekom Malaysia Berhard, and the Problem of Arbitrator Conflict of Interest, 2 Transnat'L. Disp. Mgmt. 3 (2005); Park, Arbitration's Discontents, supra note 24, at 6o2; Jan H. Dalhuisen, Legal Reasoning and Powers of International Arbitrators 29-30 (Draft Mar. 03, 2015), http://dx.doi.org/10.2139/ ssrn.2393705 (“[I]nternational arbitrators in international commerce and finance ... need not worry about the impact on the system whilst a search for consistency is also inappropriate beyond the obvious."). 
applied so rigorously in prior decisions that the applicable threshold appeared to be settled ${ }^{250}$ Yet, since the decision in Total, a much heavier burden of proof has been imposed on challenging parties, without any explanation for the abrupt change of direction.

Leaving aside the delicate question whether a formal rule of binding precedent should apply, and coherence should be pursued in substantive matters of investment law, ${ }^{251}$ it is imperative that the requirement of arbitrators' independence and impartiality be interpreted consistently. Arbitral independence and impartiality as a fundamental element of a fair and rules-based proceeding is not subject to party autonomy, and must apply uniformly to all arbitrators deciding cases under the ICSID Convention. The current unpredictability of the relevant threshold for arbitrator challenges is a significant source of legal uncertainty, which impairs the parties' confidence in the mechanism's fairness, and endangers the system's legitimacy.

The second observation is that the challenge threshold applied in the examined disqualification decisions is seldom indicative of the outcome of a proceeding. The vast majority of all disqualification requests were dismissed, even when the more lenient threshold established in Vivendi was applied. If challenges were rejected for lack of a proof of bias under the Amco Asia standard, proposals to which the Vivendi standard was applied frequently failed because the challenging party could not prove facts from which a lack of independence could reasonably be inferred, or because the inference of bias based on such facts was qualified as speculation.

Getma (where two brothers were appointed by the same party to serve as arbitrators in parallel proceedings) perfectly illustrates that the wording of the threshold for arbitrator challenges is not necessarily decisive. Whether a challenge fails because the challenging party does not furnish strict proof of bias where its inference from established facts is excluded, or whether it is

250 See Kinnear and Nitschke, supra note 13, at 48 ("The ... standard of proof ... is an objective one based on how a reasonable third party would evaluate the evidence. Proof of actual dependence or bias is not required to succeed on a challenge, and it is sufficient to establish the appearance of dependence or bias."). Chiara Giorgetti, Towards A Revised Threshold for Arbitrators' Challenges Under ICSID?, Kluwer Arbitration Blog (July 3, 2014), http://kluwerarbitrationblog.com/2014/07/03/towards-a-revised-threshold -for-arbitrators-challenges-under-icsid/.

251 See Thomas Schultz, Against Consistency in Investment Arbitration, in The Foundations of International Investment Law: Bringing Theory into Practice 297 (2013). 
unsuccessful because the challenging party's prima facie admissible inference of bias is qualified as speculation, is not of consequence. Furthermore, if inferences are in principle admissible, but arbitrators faced with challenge requests increasingly carve out exceptions to their admissibility (for example where inferences are based on family ties, or on the wrongness of a decision in fact or in law), the Vivendi standard will converge more and more with the Amco Asia standard.

Ultimately, the threshold applied to a request for disqualification may not determine whether an arbitrator remains on the tribunal or not. The focus of challenge decisions on this threshold, despite its apparent irrelevance for the outcome of disqualification proposals, may therefore give the impression that there are other, undisclosed reasons for the predominant dismissal of arbitrator challenges. To outsiders, the focus of challenge decisions on a seemingly inconsequential threshold may even look like the disguise of value judgments in legal jargon. Such an impression could severely harm the perceived legitimacy of international investment arbitration.

The following graph illustrates both the inconsistency of the threshold applied, and the lack of correlation between the applied test and the outcome of challenge proceedings (Fig. 1).

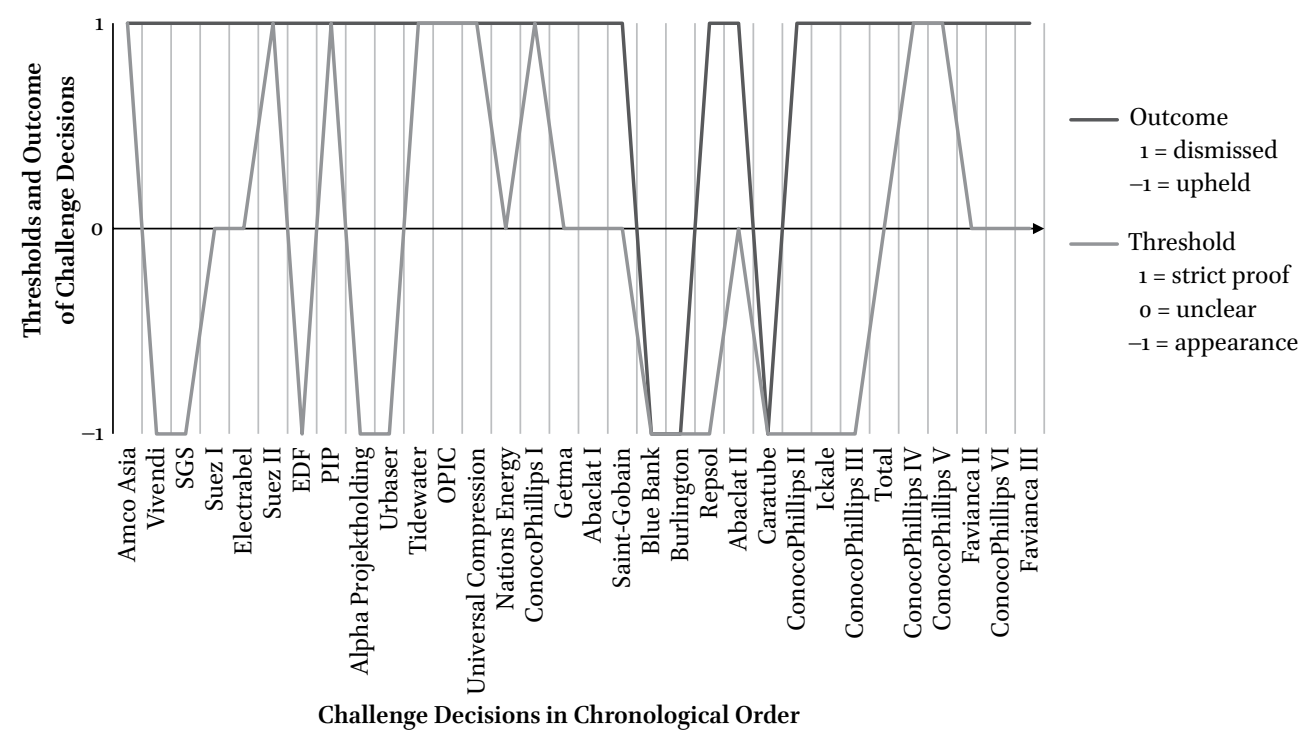

FIGURE 1 Thresholds and outcome of past ICSID challenge decisions 
The potential effect of the described deficiencies on the perceived legitimacy of the ICSID system warrants the clarification of the threshold for arbitrator challenges. Detailed suggestions for such a clarification are made in Chapter 4, Part 3 and Chapter 5 .

\section{Application of the Standard to Specific Categories of Alleged Conflict}

This Part categorizes past challenge decisions based on the grounds for disqualification invoked by the challenging parties. ${ }^{252}$ ICSID arbitrators have in the past either been challenged based on their behavior in the relevant proceeding, or based on their background. By background, this book refers to the social connections of an arbitrator, but also to the issues an arbitrator has dealt with in the past. This category will be further split up into three sub-categories, namely an arbitrator's familiarity with another participant in the proceeding, an arbitrator's familiarity with the subject-matter, and an arbitrator's connection to an adverse third party.

\subsection{Behavior in Current Proceeding}

In five of the examined challenge decisions, arbitrators were challenged because of their behavior in the current proceeding. In particular, the challenging parties argued that their decisions were so fundamentally flawed that they could only be explained by the arbitrators' manifest lack of independence and impartiality. Four of the challenges were dismissed.

$25^{2}$ For categorizations based on different criteria, see, e.g., Sheppard, supra note 32 , at 138-155 (listing relationships between an arbitrator and a party or counsel and issue conflicts as the most common grounds for arbitrator challenges); LUTTRELL, supra note 31, at 238-241 (identifying role/issue conflicts as a particularly problematic category); Caline Mouawad, Issue Conflicts in Investment Treaty Arbitration, 5 Transnat' L. Disp. Mgmt. 1-2 (2009) (distinguishing "classic" conflicts of interest, such as an arbitrator's relationship with one of the parties or its counsel, and issue conflicts, which arise from lawyers' dual roles as counsel and arbitrator, from repeat appointments, and from academic publications on issues which are subsequently brought up in a proceeding); Markert, supra note 21, at 254-268 (distinguishing social contacts, business contacts and business relationships as sources of potential hazard for arbitrator independence, and views expressed in academic publications or in awards in past arbitral proceedings, public statements regarding a proceeding, or role conflicts (concurrent roles as counsel and arbitrator in related cases) as risks to impartiality). 
In Abaclat I and II, Argentina challenged Pierre Tercier and Albert Jan van den Berg based on procedural decisions which it perceived to be unfair, and an indicator of their predisposition to its detriment. ${ }^{253}$ The Secretary-General of the PCA (who made a recommendation on the disqualification request in $\mathrm{Aba}$ clat $I^{254}$ ) and the ICSID Chairman (who decided the challenge in Abaclat II) both held that defects in a ruling alone could not be a valid basis for a disqualification. ${ }^{255}$ The challenging party would have to adduce additional evidence to prove that the members of the tribunal were influenced by criteria other than their analysis of the parties' arguments. ${ }^{256}$ The Respondent's objections were interpreted as "expressions of dissatisfaction" 257 with the tribunal's conduct of the case, and mere assertions or speculations, at best. ${ }^{258}$ The reasoning of the challenge decision in Abaclat II is extremely short, considering the gravity of the accusations raised against the arbitrators. The ICsID Chairman did not even analyze the procedural failures alleged by Argentina, seemingly holding that irrespective of the seriousness of a flaw in the substantive or formal decisions of a tribunal, bias would always need to be proven with additional facts. Abaclat I supports this reading of the decision:

[A] finding of an arbitrator's lack of independence or impartiality requires evidence other than the making of a decision which is considered to be adverse to one party or, indeed, wrong in law or insufficiently supported by reasons. ${ }^{259}$

In Burlington, Ecuador's allegation of Professor Orrega Vicuña's "blatant lack of impartiality to the detriment of Ecuador in the course of the arbitration" 260 was not even considered, but dismissed because it was belated. ${ }^{261}$ The challenge

\footnotetext{
253 Abaclat I, If 3; Abaclat II, ๆ 48-49.

254 The majority of the tribunal was challenged and Respondents requested a recommendation from the Secretary-General of the PCA, which the ICSID Chairman granted.

255 Abaclat I, ๆ 127; Abaclat II, ๆ 80.

256 Abaclat I, ๆ $980,99$.

257 Id. ๆ $82,98,102,126$. Even the issuance of the majority award without the dissenting opinion of arbitrator Abi-Saab (which was only communicated to the parties three months later) was considered a decision within the tribunal's discretion, which the Respondent was dissatisfied with. See id. $\uparrow 139$.

258 Id. $\mid 129$.

$259 \quad$ Id. ๆ 83.

260 Burlington, 920.

$261 \quad$ Id. 975.
} 
was instead upheld on the basis of comparatively minor transgressions of the arbitrator: In his comments on the request for his disqualification, Professor Orrega Vicuña admonished the challenging counsel for Respondent (Dechert LLP). He claimed that in one of its submissions, Dechert disclosed information from another proceeding which was confidential. Accordingly, he claimed, not his own behavior, but that of Dechert posed "the real ethical question." ${ }^{262}$ The ICSID Chairman upheld the challenge based on this statement, holding that it did not serve any purpose and that a third party might view it as an indication of the arbitrator's manifest lack of impartiality toward Ecuador and its counsel. ${ }^{263}$

In ConocoPhillips II, Venezuela criticized the refusal of Judge Keith and Yves Fortier Q.C. to reconsider their decision on jurisdiction, which was allegedly based on improper inferences from falsely represented facts. ${ }^{264}$ Respondent argued that the arbitrators had an "unwavering determination" to maintain their finding, irrespective of the circumstances and the truthfulness of the basis of their decision. ${ }^{265}$ As in Abaclat II, the reasoning of the dismissal of the request is very brief, in particular in light of the seriousness of Venezuela's accusations: The ICSID Chairman held that Venezuela's objections were a mere expression of its dissatisfaction with the tribunal's refusal to reconsider the case, but that said decision was within the tribunal's discretion. ${ }^{266}$

An allegedly flawed decision was also invoked as a basis for the challenge in ConocoPhillips III. Judge Keith and Yves Fortier Q.C. had refused to consent to the resignation of the third arbitrator on the tribunal, Professor Abi-Saab, arguing that it was untimely. ${ }^{267}$ Venezuela held this refusal to be an indication of the arbitrators' bias: Firstly, it questioned the arbitrators' right to make such a decision while the proceeding was suspended; ${ }^{268}$ and secondly, it denied the

\footnotetext{
$262 \quad I d .979$.

$263 \quad I d .979$.

264 ConocoPhillips II, \ๆ $17-18$.

265 Id. ๆ 22.

266 Id. ๆ $954-56$.

267 ConocoPhillips III, 9| 14-25. As had been agreed with the other arbitrators, Professor AbiSaab resigned after submitting his dissenting opinion in the case, in order to allow for a replacement arbitrator to be appointed. His dissenting opinion (and, consequently, his resignation) was however delayed, because of serious health issues he faced, and was only received seven weeks before the quantum hearing. His co-arbitrators therefore considered the resignation untimely.

$268 I d$. ๆ 43. Before Professor Abi-Saab's resignation, the challenge at issue had been submitted (only against Mr. Fortier, and on different grounds). In light of the suspension of the
} 
rightfulness of the decision, in the light of Professor Abi-Saab's serious health problems. ${ }^{269}$ The ICSID Chairman dismissed the challenge, holding that the parties' disagreement with the procedural and substantive modalities and requirements for the decision was not sufficient to demonstrate "apparent or actual bias" on the part of the two arbitrators. ${ }^{270}$

In summary, these decisions suggest that allegations of an arbitrator's (or even an entire tribunal's) objectionable behavior and ensuing flawed decision alone are not a sufficient basis for a disqualification request. Challenging parties must substantiate by what other factors the relevant arbitrator is influenced and bring additional proof for such influence.

This strict approach is reasonable in cases where the challenging party argues that the tribunal's decisions are flawed, lest the legal remedy of arbitrator challenges be used to disguise the substantive review of arbitral decisions and awards. Such a possibility to appeal does not exist in ICSID arbitration, and should not be allowed through the back door, under the guise of disqualification requests. ${ }^{271}$

Objectionable behavior by an arbitrator, however, should not per se be excluded as a basis for disqualification requests. There may arguably be cases in which a party has no insight into the reasons for an arbitrator's aversion, and is unable to produce any proof for the arbitrator's state of mind. If, in such cases, the arbitrator's behavior would cause a reasonable third person to justifiably doubt their independence or impartiality, the challenge should be upheld. There is no prevailing interest to justify categorically carving out arbitrators' behavior as a valid basis for disqualification requests.

\subsection{Familiarity with Another Participant in the Proceeding}

An overwhelming majority of the examined ICSID challenges was based on a pre-existing familiarity between an arbitrator and another participant in the proceeding. Disqualification requests were based on such circumstances in twenty-five instances. Hereinafter, challenges based on an arbitrator's prior or ongoing social or professional relations with a party or a counsel, role switching and repeat appointments are examined separately.

proceeding this entailed, it was questioned whether Judge Keith and Mr. Fortier were entitled to refuse to consent to the resignation.

$269 \quad I d$. ๆ 86.

$270 \quad I d .990$.

271 See Lee M. Caplan, Arbitrator Challenges at the Iran-United States Claims Tribunal, in Challenges and Recusals of Judges and Arbitrators in International Courts and Tribunals 115, 124-125 (Chiara Giorgetti ed., 2015). 
A

Previous Contacts with a Party or Counsel

Disqualification requests were based on (direct or indirect) relations between the challenged arbitrator and counsel on six occasions.

In Amco Asia, Indonesia challenged the Claimant-appointed arbitrator Edward W. Rubin. It argued that the relationship between Rubin and his law firm on the one hand, and Claimant's law firm on the other hand impaired his independence: Rubin's law firm had shared office space and administrative services with counsel for Claimant for about half a year into the arbitration proceedings. A long-standing profit-sharing arrangement between the firms had been discontinued before the arbitration was initiated. ${ }^{272}$ Setting a very high threshold for arbitrator challenges, the unchallenged arbitrators held that although the same degree of independence and impartiality was required of all arbitrators - whether party-appointed or presiding - acquaintances of arbitrators and parties or counsel could not, by themselves, constitute a valid basis for a disqualification request, because they were inherent in the system of partyappointments. Irrespective of the nature and extent of said relations, the challenging party would have to substantiate their request with additional facts, and prove that the arbitrator's lack of independence is "highly probable." ${ }^{273}$

In Alpha Projektholding, the Ukraine claimed that the shared educational history of the Claimant-appointed arbitrator and counsel for Claimant gave rise to justifiable doubts about the arbitrator's independence and impartiality. Dr. Turbowicz and counsel for Claimant had both studied at Harvard Law School twenty years earlier. Although the burden of proof imposed on the challenging party was much lighter than in Amco Asia, requiring the proof of facts that would at least give rise to "a readily apparent and reasonable doubt"274 about the arbitrator's reliability for independent judgment, the unchallenged arbitrators held that the facts furnished by Respondent were too meager to raise such doubts. ${ }^{275}$ Even combined with Dr. Turbowicz's lack of prior experience and expertise in transnational investment or commercial arbitration, which could arguably create the appearance that counsel for Claimant sought to appoint a puppet to the tribunal, ${ }^{276}$ the prior acquaintance was not considered a sufficient ground for disqualification.

\footnotetext{
272 Tupman, supra note 43 , at 45 .

273 Amco Asia, ๆ 9 7-8, reported in Tupman, supra note 43, at 45.

274 Alpha Projektholding, II 37.

275 Id. 141.

276 The unchallenged arbitrators' explanation of those circumstances, namely that "prior arbitral experience in an ICSID case is not a sine qua non to appointment as an ICSID arbitrator because, if it were, there would never be a first time for anyone" (id. I 70) is
} 
In Universal Compression, Venezuela challenged the Claimant-appointed arbitrator, Professor Tawil. He had allegedly entertained a professional relationship with King \& Spalding LLP (representing Claimant in the case) for over ten years, acting as their co-counsel for different investors in at least three ICSID proceedings. Furthermore, one of King \& Spalding LLP's attorneys had been employed as an associate in Professor Tawil's law firm for four years, and had as such worked with Professor Tawil personally. ${ }^{277}$ In Respondent's view, the relationship between counsel for Claimant and Professor Tawil was very significant: It afforded Claimant privileged insight into the arbitrator's viewpoints and legal thinking, thereby putting Respondent at a disadvantage in the proceeding, and created an appearance of impropriety in his appointment. ${ }^{278}$ Claimant countered that Professor Tawil's collaboration with King \& Spalding LLP was not as important and extensive as portrayed, and that counsel for Respondent equally employed former team-members of Professor Tawil. ${ }^{279}$ The ICSID Chairman rejected the proposal for disqualification, holding that the challenging party had failed to establish objective facts proving the arbitrator's manifest lack of independence or impartiality. ${ }^{280}$ In particular, there was no ongoing relationship between Professor Tawil and counsel for Claimant, and the cases on which they had collaborated involved different parties, different facts, and possibly different legal issues. ${ }^{281}$ Professor Tawil's acquaintance with an attorney on the team of counsel for Claimant was considered unproblematic since the attorney had only been one of several junior associates on the team, and had switched law firms five years earlier.

In Nations Energy, Dr. Alexandrov, a member of the ad hoc Committee constituted for the annulment proceeding, was challenged by Claimant. One of Respondent's counsel had previously worked directly together with him: During the attorney's seven year employment with Sidley Austin LLP, Dr. Alexandrov allegedly supervised him in his work on several ICSID proceedings. ${ }^{282}$ The argumentation of Claimant was similar to that of Respondent in Universal Compression, alleging that the former co-worker's privileged insight into Dr. Alexandrov's views would put Claimant at a disadvantage. The unchallenged

implausible, in light of how long-winded the career path of arbitration professionals generally is. This path hardly ever starts on an arbitration panel.

277 Universal Compression, $\mathbb{\uparrow} \mathbf{9} 15$ and 50.

278 Id. ๆฯ $5^{1-53}$ and $97-98$.

279 Id. 956.

$28 \mathrm{o} \quad \mathrm{Id}$. 77 .

$281 \quad I d .9102$.

$282 \quad$ Nations Energy, 922. 
arbitrators rejected the disqualification proposal. They held that the establishment of a non-exclusive relationship of unproven extent and intensity between the two was by itself insufficient proof of a manifest lack of independence and impartiality. ${ }^{283}$ Claimant would have had to furnish objective evidence of the influence of said relationship on Dr. Alexandrov's judgment, namely the arbitrator's ensuing predisposition in favor of Respondent ${ }^{284}$ - an extremely high burden of proof.

Another arbitrator challenge was dismissed in Repsol. Argentina requested the disqualification of Dr. Claus von Wobeser on the basis of his previous collaboration with the law firm Freshfields Bruckhaus Deringer LLP (hereinafter Freshfields), as a co-counsel in a commercial arbitration. Freshfields represented the Claimant in Repsol. The ICSID Chairman held that the commercial arbitration case, which was decided nine years earlier, was unrelated to the present dispute, and that Dr. von Wobeser's role in the case was limited to his expert testimony on Mexican law. Accordingly, this circumstance did not suffice as a ground for disqualification. ${ }^{285}$

Teresa Cheng was equally challenged based on her connection to Freshfields in Total, where Freshfields represented the Claimant. Ms. Cheng had given legal advice and acted as a legal counsel for clients of Freshfields in two isolated instances, had acted as a Claimant-appointed arbitrator in a commercial arbitration against a party represented by Freshfields, and her son had completed a summer internship in the Paris office of the law firm. ${ }^{286}$ The two unchallenged Annulment Committee members held that Argentina failed to substantiate the existence of a relationship of dependency between Ms. Cheng and Freshfields, since the contacts were sporadic and informal. ${ }^{287}$ The mere existence of some sort of professional relationship with another participant in the proceeding, they stressed, was not an automatic ground for disqualification. Instead, the connection had to be important enough - in the light of the circumstances as a whole - to raise doubts regarding the decision-maker's ability to decide freely and independently. ${ }^{288}$ They denied that this was the case in Total. The isolated events invoked by Argentina had occurred over the course of many years, and were unrelated to each other or to the proceeding at

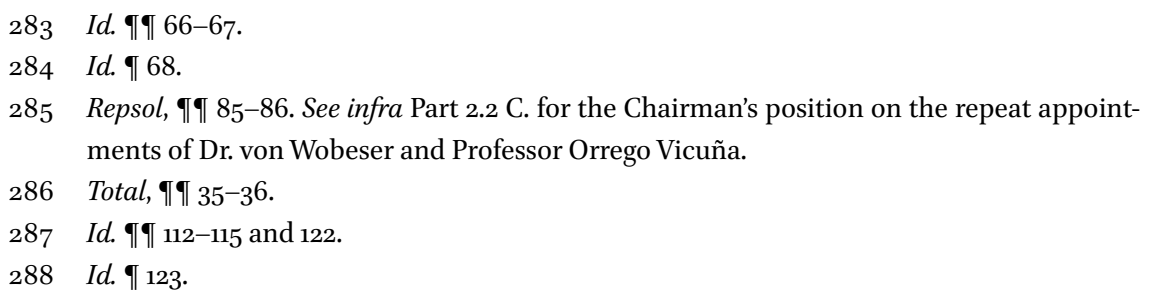


issue. ${ }^{289}$ Whether they were viewed independently or as a whole, these events did not reasonably indicate the existence of a bond which would manifestly impede Ms. Cheng's ability to decide independently and impartially.290

In Vannessa Ventures, the chairman of the tribunal, V.V. Veeder, Q.C., handed in his resignation without being challenged, when his co-counsel in another, unrelated but ongoing arbitration appeared as counsel for Claimant at the jurisdictional hearing. ${ }^{291}$

In six cases, the (direct or indirect) connection between the challenged arbitrator and one of the parties was invoked as a basis for the request for disqualification. ${ }^{292}$

In Amco Asia, the Claimant-appointed arbitrator Edward W. Rubin had for several years personally advised a controlling shareholder of the corporate Claimants on tax matters before being appointed as an arbitrator (but after the arbitration proceedings were initiated). ${ }^{293}$ As has been stated above, the unchallenged arbitrators dismissed the request for disqualification. They held that in contrast to a regular attorney-client relationship, the provision of legal advice in a single matter would not impact the reliability of the arbitrator for independent and impartial judgment. ${ }^{294}$

In Vivendi, Argentina requested the disqualification of Mr. Yves Fortier, Q.C., the president of the ad hoc Committee, based on an ongoing attorney-client relationship between one of the partners in Mr. Fortier's law firm and a corporate predecessor of one of the Claimants. The unchallenged ad hoc Committee members rejected the challenge, highlighting that Mr. Fortier had immediately and fully disclosed the mandate, although he was not personally involved in it, and although it was unrelated to the dispute at hand. ${ }^{295}$ The specificity of the mandate (which concerned a soon to be closed transaction) seemed to play a role in the decision - the matter may have been resolved differently if the partner had given general legal or strategic advice to the company. ${ }^{296}$

\footnotetext{
289 Id. $\mid 127$.

$290 \quad I d .9125$.

291 Vannessa Ventures Ltd. v. Bolivarian Republic of Venezuela (Vannessa Ventures), ICSID Case No. ARB(AF)/04/6 (reported in Sheppard, supra note 32, at 149.).

292 A challenge was obviated in the very first ICsID arbitration, Holiday Inns S.A. and others v. Morocco (ICSID Case No. ARB/72/1), when Claimant-appointed arbitrator John Foster resigned upon becoming one of the corporate Claimants' directors. Tupman, supra note 43, at 44; Sheppard, supra note 32 , at $138-139$.

293 Vivendi, 921.

294 Tupman, supra note 43, at 45.

295 Vivendi, ๆ 15; Bernasconi-Osterwalder, Johnson, and Marshall, supra note 32, at 23.

296 See Vivendi, ๆ 26.
} 
A successful proposal for disqualification was made by Venezuela in Blue Bank, based on the attorney-client relationship of the arbitrator's firm with the Claimant. The Claimant-appointed arbitrator (José María Alonso) was a partner at Baker \& McKenzie Madrid. Baker \& McKenzie New York and Baker \& McKenzie Caracas simultaneously advised the Claimant on an ongoing unrelated proceeding ${ }^{297}$ against the same Respondent, which concerned similar issues. In his function as an arbitrator in Blue Bank, Mr. Alonso would have been in a position to decide issues relevant to the parallel proceeding led by his colleagues. Respondent claimed that "any reasonable person would have justifiable doubts as to whether an arbitrator that coordinates the global arbitration practice of a firm could sign an award rejecting arguments that are being defended by other partners of the same firm against the same Respondent."298 The ICSID Chairman upheld the challenge of Mr. Alonso based on an appearance of a lack of impartiality resulting from the cumulation of several facts. ${ }^{299}$ Mr. Alonso's membership on Baker \& McKenzie's international arbitration steering committee, and the partial dependency of his remuneration on the results achieved by firms other than Baker \& McKenzie Madrid seem to have affected the Chairman's decision.

Three of the challenges were dismissed in unpublished decisions. In Zhinvali, the unchallenged arbitrators held that in the absence of a professional or business relationship, or any other facts, it was purely speculative to "suggest that a merely occasional personal contact could manifestly affect the judgment of an arbitrator." ${ }^{300}$ In Generation Ukraine, ${ }^{301}$ Claimant requested the disqualification of Dr. Jürgen Voss, alleging that he had developed personal connections with Ukrainian officials in his role as Deputy General Counsel of the Multilateral Investment Guarantee Agency (MIGA). ${ }^{302}$ The challenge was rejected based on a recommendation of the Secretary-General of the PCA, ${ }^{303}$

\footnotetext{
297 Longreef Investments A.V.V.v. Bolivarian Republic of Venezuela, ICsID Case No. ARB/11/5.

298 Blue Bank, 931.

299 Id. \⿻ 67-69.

300 Zhinvali Development Ltd. v. Republic of Georgia (Zhinvali), ICSID Case No. ARB/oo/1, Decision on a Proposal to Disqualify an Arbitrator (Jan. 19, 2001), unpublished, referenced in Vivendi, \ 23. See Sheppard, supra note 32, at 139; Markert, supra note 21, at 254; LuTTRELL, supra note 31, at 226.

301 Generation Ukraine Inc. v. Ukraine (Generation Ukraine), ICSID Case No. ARB/oo/9.

302 LUTTRELL, supra note 31, at 230.

303 The unchallenged arbitrators were divided on the proposal and left it for the ICSID Chairman to decide. Because a decision of the latter on the disqualification of Dr. Voss might have been considered a breach of the principle of nemo judex in sua causa (the ICSID Chairman is the President of the World Bank, and Dr. Voss was challenged based on his
} 
for reasons which have not been made public. Finally, in Lemire, the Ukraine challenged the arbitrator it had itself appointed, Jan Paulsson. His law firm (Freshfields) simultaneously represented the Ukraine in an unrelated investment arbitration. ${ }^{304}$ The unchallenged arbitrators' arguments for the dismissal of the challenge are unknown. In any event, the case is not representative, considering that Mr. Paulsson was challenged by his appointing party, whom his firm represented in a parallel proceeding. ${ }^{305}$

In summary, ten of the eleven challenges based on previous (direct or indirect) contacts between an arbitrator and a party or counsel were dismissed. In one decision, the prior acquaintance of an arbitrator with counsel was generally carved out as a valid ground for disqualification. In most other decisions, the circumstances were held not to be so grave as to prove bias or raise doubts about the arbitrator's independence and impartiality - even where the arbitrator had a long-standing relationship with her or his appointing party or counsel.

As has been previously stated, the meaningful exercise of the parties' right to appoint their decision-makers requires them to be able to evaluate the candidate's suitability and qualifications. This, in turn, presupposes a certain degree of familiarity with the arbitrator. It does not, however, justify the tolerance of any and all relations, irrespective of their duration and intensity. On the contrary, it is important for the legitimacy of the ICsID system that a clear demarcation line be drawn between permitted and improper relationships between an arbitrator and another participant in the proceedings.

The circumstances which were invoked in the only disqualification request that was upheld were extraordinary. Members of the same firm (although in different offices) were concurrently dealing with similar issues in a dispute

relationship with a World Bank agency), the President of the ICSID referred the challenge to the Secretary-General of the PCA. See LUTTRELL, supra note 31, at 230.

304 Joseph C. Lemire v. Ukraine, ICSID Case No. ARB(AF)/98/1, reported in Luke Eric Peterson, ICSID Arbitrators Reject Challenge to Third Member of Tribunal in Lemire v. Ukraine Arbitration, Investment Arbitration Reporter (Oct. 1, 2008), http://iareporter.developerspace.co.vu/icsid-arbitrators-reject-challenge-to-third-member-of-tribunal-in-lemire-vukraine-arbitration/ [hereinafter Peterson, Lemire]; Sheppard, supra note 32, at 143-144.

305 Reportedly, the Ukraine preemptively challenged Mr. Paulsson, because Claimant did not provide the requested assurances not to seek annulment of a potentially unfavorable arbitral award. In fact, however, both Claimant and its counsel assured the Ukraine that they would not seek an annulment - just not in the exact format requested. Against this background, the Ukraine's pursuance of challenge proceedings appears to have been a mere delaying tactic. See Peterson, Lemire, supra note 292. 
between the same parties. The challenged arbitrator could have prejudged issues relevant for his colleagues, who represented the Claimant in the second case. The appearance of a lack of impartiality was undeniable.

\section{B Role Switching between an Arbitrator and Counsel}

In three instances, requests for the disqualification of an arbitrator were based on the interchanging roles of the same arbitrators and counsel in several proceedings.

One of those challenge proceedings was $s G s$. The professional paths of the arbitrator appointed by Respondent (Mr. J. Christopher Thomas) and counsel for Respondent (Mr. Jan Paulsson) had crossed on several occasions in the past, where the roles were reversed: Mr. Thomas had acted as counsel for Respondent in two proceedings ${ }^{306}$ in which Mr. Paulsson presided over the tribunals. ${ }^{307}$ In one of these proceedings, the tribunal dismissed all claims against the Respondent State (Mexico) represented by Mr. Thomas. As evidenced by a previously disclosed retainer of Mr. Thomas with Mexico, the latter was a very important client of his firm. Accordingly, Claimant in $s G s$ argued that it was concerned that Mr. Thomas might - consciously or subconsciously - feel indebted to Mr. Paulsson and therefore not approach the case with the required open-mindedness. ${ }^{308}$ The unchallenged arbitrators dismissed the Claimant's doubts out of hand, labelling its concerns as mere supposition and speculation. If the Claimant meant to imply that Mr. Thomas and Mr. Paulsson would favor each other's clients, it would have to furnish proof for such "reciprocal partisanship." 309

In another set of cases, the challenged arbitrator (Dr. Andres Rigo Sureda) presided over two disputes, Azurix and Siemens. ${ }^{310}$ Counsel for Claimant in those disputes (Guido Santiago Tawil) simultaneously acted as the Claimantappointed arbitrator in a third dispute, Duke Energy International, ${ }^{311}$ in which

306 GAMI Investments, Inc. v. The Government of the United Mexican States, see GAMI Investments Inc. v. United Mexican States, U.S. Department of State, http://www.state .gov/s/l/c7119.htm (last accessed on Dec. 30, 2016); Robert Azinian and others v. United Mexican States, ICSID Case No. ARB(AF)/97/2.

$307 s G s, \boldsymbol{\Psi} \mathbb{9} 9$ and 12.

308 Id. 113.

309 Id. ๆ $25^{-26 .}$

310 Azurix Corp. v. Argentine Republic (Azurix), ICSID Case No. ARB/o1/12; Siemens A.G. v. Argentine Republic (Siemens), ICSID Case No. ARB/02/8.

311 Duke Energy International Peru Investments No. 1 Ltd. v. Republic of Peru, ICSID Case No. $\mathrm{ARB} / 03 / 28$. 
Dr. Rigo Sureda's law firm (Fulbright \& Jaworski LLP) represented Claimant. ${ }^{312}$ Mr. Tawil thus pleaded two cases before Mr. Sureda, while Mr. Sureda's law firm argued a claim before Mr. Tawil. Argentina requested the disqualification of Mr. Sureda in both Azurix and Siemens. While the challenge proceedings were ongoing, Mr. Sureda terminated his employment with Fulbright \& Jaworski LLP. ${ }^{313}$ In Azurix, the challenge was dismissed by the unchallenged arbitrators. The reasons for the rejection are unfortunately unknown, since the decision was not published. ${ }^{314}$ In Siemens, the ICsID Chairman rejected the challenge without giving reasons, after the unchallenged arbitrators failed to agree on the request. 315

It is regrettable that the reasons for the dismissal of the disqualification requests in two out of three challenges based on role switching are unknown. The burden of proof imposed on the challenging party in the only reasoned decision, $s G s$, is remarkably heavy, and virtually impossible to fulfill. $s G s$, which was decided over ten years ago, can hardly provide an authoritative benchmark for challenges based on role switching. The lack of agreement among the unchallenged arbitrators in Siemens on the disqualification of Dr. Sureda suggests that the ICSID arbitration community does not perceive role switching to be per se unproblematic and harmless.

\section{C}

\section{Repeat Appointments}

In thirteen instances, arbitrators were challenged based on their repeated appointment by the same party or law firm in successive or parallel proceedings, or in proceedings against the same Respondent.

In Electrabel, Professor Brigitte Stern was challenged because of her parallel appointment by Hungary and Arnold \& Porter LLP in another proceeding. ${ }^{316}$ The unchallenged arbitrators dismissed the challenge, arguing that the parallel

312 International Institute for Sustainable Development, ICSID Tribunals diverge over independence of arbitrator to hear Argentine claims, INVEST-SD: Investment Law and Policy News Bulletin (Mar. 24, 2005), http://www.iisd.org/pdf/2005/investment_investsd _mar24_2005.pdf.

313 Bernasconi-Osterwalder, Johnson, and Marshall, supra note 32, at 26.

314 Sheppard, supra note 32, at 145-146.

315 Id. at $145^{-146}$ (explaining that "Professor Domingo Bello Janeiro thought Dr. Rigo Sureda's resignation from Fulbright was implicit of his lack of independence; while Judge Brower thought that it acted 'to silence any conceivable lingering doubts' as to his independence.").

316 The parallel proceeding was AEs Summit Generation v. Republic of Hungary, ICSID Case No. ARB/o7/22. See Electrabel, \ף 29 and 37; Sheppard, supra note 32, at 154. 
appointment by the same party and law firm, in a case concerning the same agreements, the same government action, and the same treaty, were harmless. ${ }^{317}$ The only potential red flag, they held, was if the cases really arose from similar factual circumstances. Whether this was the case, however, could not be ascertained at this stage of the proceedings. ${ }^{318}$

The Claimant-appointed arbitrator in PIP, Professor Ibrahim Fadlallah, had served as the chair of the tribunal in a previous proceeding against Gabon, ${ }^{319}$ in which an award was rendered one year earlier. Said award was received with much opposition from Gabon, and the annulment proceeding was ongoing. ${ }^{320}$ Gabon requested Professor Fadlallah's disqualification, arguing that the cases referred to similar questions of fact and of law, and that the arbitrator's role in the previous case raised reasonable doubts about his ability to approach $P I P$ with the required objectivity and open-mindedness. ${ }^{321}$ Furthermore, the knowledge he acquired in the context of Transgabonais was alleged to endanger the balance of information on the tribunal. ${ }^{322}$ The ICsid Chairman highlighted that neither the prior adjudication of Gabon's rights by Professor Fadlallah, nor Gabon's initiation of an annulment proceeding in the case presided over by him were sufficient grounds for disqualification. ${ }^{323}$ In other words, the repeat appointment of an arbitrator against a particular Respondent is presumed to be unproblematic, even if the Respondent is still challenging the previous award in an annulment proceeding. Furthermore, the ICSID Chairman held that it was not established that Transgabonais and PIP concerned the same facts and the same legal issues; accordingly, the risk of an imbalance of information on the tribunal was not manifest, ${ }^{324}$ and the proposal was rejected.

In Tidewater and Universal Compression, Respondent-appointed arbitrator Professor Brigitte Stern was challenged based on her repeat appointments ${ }^{325}$

\footnotetext{
317 Electrabel, ๆ 39 (" ${ }^{7}$ remains o and not 7 . Two or more factors which do not satisfy the test required under Article 57 cannot, be mere 'combination,' meet that test.").

318 Id. 940.

319 Compagnie d'Exploitation du Chemin de Fer Transgabonais v. Gabonese Republic (Transgabonais), ICSID Case No. ARB/04/5.

$320 \quad P I P, \mathbb{~} 15$.

$321 \quad I d .914$.

322 Id. 915.

323 Id. ๆ 28 and 30.

324 Id. ๆ $13^{2-33}$.

325 Aside from Tidewater and Universal Compression, Venezuela had appointed her to the tribunals in Vannessa Ventures and Brandes Investment Partners LP v. The Bolivarian Republic of Venezuela (Brandes), ICsid Case No. ARB/o8/3.
} 
by Venezuela and its outside counsel Curtis, Mallet-Prevost, Colt \& Mosle LLP. The challenging parties' disqualification requests were largely based on the same argument: They claimed that Professor Stern's repeated appointment by the same actors created the appearance of undue influence and an advantage for the appointing party. In particular, they feared that her previous role in cases which were based on overlapping facts and legal questions ${ }^{326}$ might (even unconsciously, and despite her experience and standing ${ }^{327}$ ) cause her to approach the present disputes in a less open-minded way. ${ }^{328}$ The fact that she would hear Venezuela's explanations for a third or fourth time by the time of the hearings, but only learn the Claimants' positions once, was alleged to cause an unfair imbalance between the parties. ${ }^{329}$ The Tidewater challenge was adjudicated by the unchallenged co-arbitrators, while the disqualification request in Universal Compression was decided by the ICSID Chairman, due to the simultaneous challenge of Professor Tawil. ${ }^{330}$ Both instances viewed the circumstances through a very similar lens, and dismissed the proposals. Multiple appointments by the same party or counsel were held not to be sufficient indicators of a manifest lack of independence or impartiality. ${ }^{331}$ In Tidewater, the unchallenged arbitrators clarified:

The starting-point is that multiple appointments as arbitrator by the same party in unrelated cases are neutral, since in each case the arbitrator exercises the same independent arbitral function. ${ }^{332}$

The conclusion of both decisions seemed to be the observation that Professor Stern serves as an arbitrator in so many disputes that she is not dependent on any one party. Her repeat appointment in three or four cases thus did not create an appearance of dependency. ${ }^{333}$ With regard to Claimants' apprehension of an issue conflict or unconscious bias on the part of Professor Stern, both instances were reluctant to assume an overlap of the pertinent facts and

326 An overlap of the facts and the law was only argued in Universal Compression. In Tidewater, the challenging party merely pleaded that the tribunal would have to answer the same jurisdictional questions.

327 Tidewater, $\mathbb{\Upsilon} 15$.

328 Id. ๆ 13; Universal Compression, ๆ 24.

329 Tidewater, \| 13; Universal Compression, \ 24.

330 Supra Part 2.2 A.

331 Universal Compression, $\uparrow$ ๆ 77 and 86.

332 Tidewater, $\mathbb{\Upsilon} 60$.

333 Id. ๆ 64; Universal Compression, ๆ 77 and 87. 
law before they were pleaded, ${ }^{334}$ besides stressing that investment arbitration would become unworkable if arbitrators were not allowed to adjudicate "similar legal or factual issues in concurrent or consecutive arbitrations." 335 The intimation that Professor Stern might not be as open-minded about Venezuela's actions and defenses, after having been exposed to their repeated portrayal by the Respondent, was dismissed as speculative. ${ }^{336}$

In OPIC and Ickale, Professor Philippe Sands was challenged because of his repeat appointments by the respective Respondent States (Venezuela and Turkmenistan) and their counsel (Curtis, Mallet-Prevost, Colt \& Mosle LLP). Aside from being directed against the same arbitrator, the disqualification proposals were quite dissimilar. In OPIC, the Claimant asserted a lack of independence of Professor Sands, arguing that his repeat appointment by Venezuela and its counsel in three cases created a potential for undue influence and for an unfair advantage. Claimant pleaded that Professor Sands's financial compensation as an ICSID arbitrator was impacted by the repeat appointments, and that he was therefore indebted to his appointers. ${ }^{337}$ The disqualification proposal was dismissed because the facts did not quite lend themselves to an inference of bias, ${ }^{338}$ but not without an important correction of the decision in Tidewater: The unchallenged arbitrators stressed that repeat appointments were not a neutral factor but an important element to be considered in the evaluation of a disqualification request, since the perceived legitimacy of investor-State dispute settlement depended on its users' impression of and belief in the arbitrators' independence. ${ }^{339}$ The unchallenged arbitrators' approach to repeat appointments was surprisingly critical:

334 Tidewater, \ 69; Universal Compression, $\uparrow$ 82. This objection misses the point that the facts and the law of the case will frequently not have been pleaded at the stage of a disqualification proposal - in many cases, the challenge would otherwise be belated.

335 Tidewater, ๆ 68; see also Universal Compression, ๆ 83.

336 Universal Compression, ๆ 78.

337 OPIC, ๆ 1 21-22.

338 The previous two appointments of Professor Sands by Venezuela had never materialized - they had in fact concerned the same dispute, which was filed in several fora. The UNCITRAL tribunal rejected its jurisdiction, and the tribunal under the Arbitration Rules of Nova Scotia was never constituted. The repeat appointments by counsel for Respondent were unrelated to the case at hand and concerned another Respondent State (Turkmenistan); hence they were considered unproblematic. Finally, allegations of a financial dependence were rejected based on Sands's "extensive independent income sources unrelated to fees derived from his appointments as arbitrator in investment arbitrations." (OPIC, ๆ 151,53 and 55 ). 
The suggestion by the arbitrators in Tidewater that multiple appointments are likely to be explicable on the basis of a party's perception of the independence and competence of the oft appointed arbitrator is in our view unpersuasive. In a dispute resolution environment, a party's choice of arbitrator involves a forensic decision that is clearly related to a judgment by the appointing party and its counsel of its prospects of success in the dispute. In our view, multiple appointments of an arbitrator are an objective indication of the view of parties and their counsel that the outcome of the dispute is more likely to be successful with the multiple appointee as a member of the tribunal than would otherwise be the case. ${ }^{340}$

In Ickale, on the other hand, Turkmenistan invoked impartiality arguments: The prior exposure of Professor Sands to the same issues (in particular of fact, but also of law) $)^{341}$ was claimed to result in his diminished objectivity and open-mindedness, as well as an imbalance of knowledge on the tribunal. ${ }^{342}$ This appearance of partiality was said to be reinforced by Professor Sands's appointment by counsel for Respondent in two other cases, one of which was also directed against Turkmenistan, but concerned different issues. ${ }^{343}$ The unchallenged arbitrators dismissed the challenge. They held that it was not enough that Professor Sands was exposed to the same threshold jurisdictional question in Ickale and in Kilic - an overlap of the facts relevant for the determination of the tribunal's jurisdiction (as opposed to facts relevant for the decision on the merits) could not indicate a manifest lack of impartiality. ${ }^{344}$ The unchallenged arbitrators further stressed that Professor Sands had not made any statements that would put his impartiality into question, and that they trusted his assurances of approaching the case with an open mind. ${ }^{345}$

In two cases which were both decided by the ICSID Chairman on the same day (Burlington and Repsol), Professor Orrego Vicuña was challenged based on his repeat appointments against Argentina. In Repsol, Argentina argued that the annulment of three ICSID awards previously rendered in its

\footnotetext{
$340 \quad I d$.

341 Ickale, ๆ 74.

342 Id. ๆף 72-73 (referring to Professor Sands's appointment by Turkmenistan and Curtis, Mallet-Prevost, Colt \& Mosle LLP in Kılıç İnşaat İthalat İhracat Sanayi ve Ticaret Anonim Şirketi v. Turkmenistan (Kilic), ICSID Case No. ARB/10/1).

343 Adem Dogan v. Turkmenistan, ICSID Case No. ARB/og/9; and opIc. See Ickale, \ 76.

344 Ickale, ๆ 120.

345 Ickale, ๆ 122.
} 
detriment by tribunals presided by Professor Orrego Vicuña ${ }^{346}$ caused him to bear a manifest animosity against Argentina. Never before in the history of ICSID had three awards signed by the same presiding arbitrator been annulled - let alone at the request of the same party. In the light of such a devastating verdict on an arbitrator's competence, it was unreasonable to expect him to impartially judge over Argentina. ${ }^{347}$ Furthermore, Argentina claimed that Repsol would concern the same facts (emergency measures) and law (the defense of necessity) argued in the previous three cases, which would only reinforce its argument. ${ }^{348}$ The arbitrator's attempt to justify his position in the annulled cases in academic writing ${ }^{349}$ was said to be further proof of his prejudice and in itself a cause for disqualification. ${ }^{350}$ The ICSID Chairman dismissed the challenge. He held that $c M s$, Enron and Sempra were based on different facts and law, and concerned State actions taken at different periods than those in Repsol. Argentina's successful requests for annulment in the past were deemed insufficient evidence of Professor Orrega Vicuña's manifest lack of impartiality. ${ }^{351}$ His publication on the necessity defense was considered irrelevant, because no such provision was contained in the invoked legal instrument. ${ }^{352}$

In the same case, Claus von Wobeser was challenged based on his prior appointment in an ICSID proceeding against Argentina, ${ }^{353}$ arguing that said (singular) appointment put him into a generally adverse position toward the

346 CMs Gas Transmission Company v. Argentine Republic ( $c M s)$, ICSID Case No. ARB/o1/8, Decision of the ad hoc Committee on the Application for Annulment of the Argentine Republic (Sept. 25, 2007); Sempra Energy International v. Argentine Republic (Sempra), ICSID Case No. ARB/02/16, Decision on Annulment (June 29, 2010); Enron Creditors Recovery Corporation (formerly Enron Corporation) and Ponderosa Assets, L.P. v. Argentine Republic (Enron), ICSID Case No. ARB/o1/3, Decision on Annulment (July 30, 2010).

347 Repsol, $ๆ$ ๆ 25-26.

348 Id. $ๆ 28$.

349 Francisco Orrego Vicuña, Softening Necessity, in Looking to the Future. Essays on International LaW in Honor of W. Michael Reisman 741 (Mahnoush H. Arsanjani et al. eds., 2010).

350 Repsol, ๆๆ 29-30.

351 Id. ๆฯ $77-78$.

$35^{2} I d$. 97 . Considering that the defense of necessity is regularly invoked based on customary international law, this argument is difficult to grasp.

353 Von Wobeser was appointed by the investor in CIT Group Inc. v. Argentine Republic (CIT), ICSID Case No. ARB/04/9. In Repsol, he was also challenged based on his previous collaboration with counsel for Claimant (Freshfields). This aspect of the challenge is examined supra in Part 2.2 A. 
country. Furthermore, the emergency measures adjudicated in $C I T$ would again be relevant in Repsol. ${ }^{354}$ The ICSID Chairman was not convinced by Argentina's arguments: $C I T$ had concerned different facts and a different treaty, and had moreover been concluded by a settlement of the parties, and not by an award on the merits. ${ }^{355}$

Professor Orrego Vicuña's challenge in Burlington was brought by Ecuador. It was mainly based on his appointment by Freshfields in seven prior ICSID proceedings between 2007 and 2013. ${ }^{356}$ Ecuador argued that the appointment by Freshfields in such a high number of cases undermined the Professor's independence. ${ }^{357}$ The request for disqualification was dismissed as far as it relied on those grounds, because it had not been raised in a timely manner. ${ }^{358}$ Accordingly, the challenge decision does not state whether the repeated appointment of an arbitrator by the same law firm in so many cases creates an appearance of dependence. The request for disqualification was however upheld on other grounds. ${ }^{359}$

The request for Bruno Boesch's disqualification in Caratube was upheld. Claimant had criticized his repeat appointment by Kazakhstan and its counsel (Curtis, Mallet-Prevost, Colt \& Mosle LLP) in the highly similar parallel case Ruby Roz. ${ }^{360}$ The facts and the law pleaded in Ruby Roz were essentially the same as in Caratube, and the parties relied on the same witnesses, experts and evidence. ${ }^{361}$ In Claimant's view, Mr. Boesch's knowledge of the parties' arguments on jurisdiction and on the merits led to a "manifest risk of prejudgment," which could not be removed by his assurances to the contrary. ${ }^{362}$ His appointment by Curtis, Mallet-Prevost, Colt \& Mosle LLP in at least two

\footnotetext{
354 Repsol, $\llbracket$ ๆ $5^{0-51 .}$

355 Id. $\uparrow 83$.

356 Eni Dación B.V. v. Bolivarian Republic of Venezuela, ICSID Case No. ARB/o7/4; Itera International Energy LLC and Itera Group NV v. Georgia, ICSID Case No. ARB/08/7; EVN AG v. former Yugoslav Republic of Macedonia, ICSID Case No. ARB/og/10; Pan American Energy LLC v. Plurinational State of Bolivia, ICSID Case No. ARB/10/8; Ampal-American Israel Corporation and others v. Arab Republic of Egypt, ICSID Case No. ARB/12/11; Rusoro Mining Ltd. v. Bolivarian Republic of Venezuela (Rusoro), ICsid Case No. ARB(AF)/12/5, Decision on the Proposal for the Disqualification of Francisco Orrego Vicuña (June 14, 2013); Repsol.

357 Burlington, 924.

$35^{8} \quad$ Id. $\ 75$.

359 Id. \ 79, see supra Part 3.1.

36o Ruby Roz Agricol and Kaseem Omar v. Kazakhstan (Ruby Roz), UnCitraL.

361 Caratube, ๆ

$362 \quad$ Id. $\uparrow 27$.
} 
additional cases was argued to raise serious doubts about his independence, in particular in light of his lack of prior experience with ICSID arbitration. ${ }^{363}$ The unchallenged arbitrators, for the first time in the history of ICSID, ${ }^{364}$ upheld the challenge of their co-arbitrator. They explained that nobody could realistically maintain a "Chinese wall" in their mind, and avoid their decision from being influenced by knowledge from previous proceedings. Accordingly, the repeat appointment of an arbitrator in very similar cases could lead to prejudgment. ${ }^{365}$ Since there was such a strong overlap of the relevant facts and law in Ruby Roz and Caratube, ${ }^{366}$ the unchallenged arbitrators concluded that a reasonable and informed third party would find it highly likely that Mr. Boesch could not be completely objective and open-minded, but would be prejudiced. Accordingly, they affirmed the existence of an "evident or obvious appearance of a lack of impartiality."367 Upholding the challenge on this basis, the unchallenged arbitrators left open the question whether an imbalance of knowledge on the tribunal could constitute a free-standing ground for disqualification, or whether it was only an aggravating circumstance. ${ }^{368}$ They did, however, consider whether repeat appointments by the same law firm were sufficient to infer a manifest lack of independence and impartiality, and answered in the negative. In a system of party-appointments, they thought it unavoidable that every side would appoint the "best" arbitrator, ideally someone they had previously successfully worked with. ${ }^{369}$

In Suez I, Argentina argued that Professor Gabrielle Kaufmann-Kohler's involvement in the allegedly flawed decision in Vivendi was evidence of her lack of independence and impartiality. ${ }^{370}$ The unchallenged arbitrators dismissed the disqualification request as belated, but not without stating, in the form of obiter dicta, that the text of the unanimous decision in Vivendi did not furnish proof of bias and that stronger evidence than a mere difference in opinion or a wrong decision was required to substantiate a prejudgment. ${ }^{371}$ Since the facts and the applicable law were distinctly different in Vivendi and Suez I, Argentina's request was rejected as based on mere belief, and not facts.

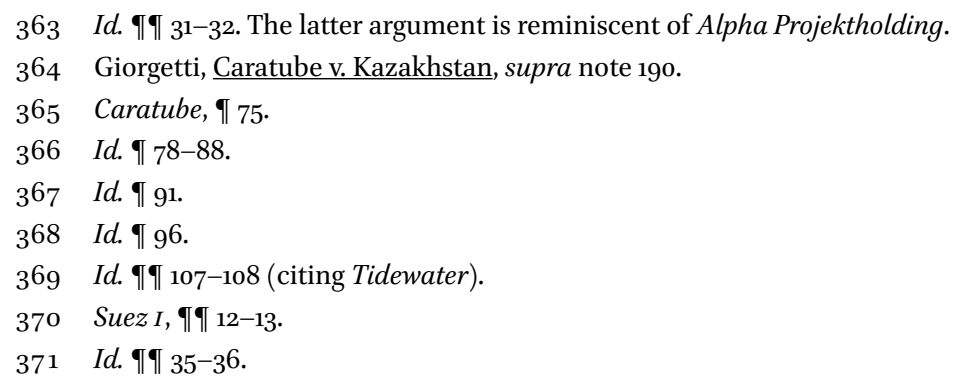


Beyond these published cases, disqualification requests based on repeat appointments were filed and dismissed in two unpublished cases:

In Saba Fakes, ${ }^{372}$ the unchallenged arbitrators dismissed a request for the disqualification of Professor Laurent Levy. Turkey had already appointed him in a previous, unrelated proceeding which allegedly concerned similar facts. The reasons for the rejection of the challenge are unknown. Rusoro concerns another disqualification request aimed at Professor Francisco Orrega Vicuña, because of his repeat appointments by Freshfields. The challenge was rejected. 373

In summary, only one of thirteen challenges based on repeat appointments was upheld. The circumstances in Caratube were extraordinary: Mr. Boesch was appointed in two parallel cases, which were essentially identical, making it difficult to deny an appearance of prejudgment. Accordingly, his disqualification was virtually unavoidable.

\subsection{Familiarity with the Subject-matter of the Proceeding}

In three instances, arbitrators were challenged because they had previously dealt with and issued statements on similar issues. Their familiarity with the subject-matter and expression of their views in different roles - be it as government officials or as scholars - was argued to impede their free and unaffected decision-making.

In Saint-Gobain, Gabriel Bottini (the arbitrator appointed by Venezuela) was challenged based on his previous employment as the National Director of International Matters and Disputes for the Office of the Attorney General of Argentina. In this role, Claimant argued, he defended Argentinian interests from claims based on "precisely the same or similar issues" as in the case at hand. ${ }^{374}$ Accordingly, the Claimant questioned Mr. Bottini's ability to argue differently in his role as an arbitrator. ${ }^{375}$ The unchallenged arbitrators held that it is not unthinkable that a lawyer who has taken a certain stance in the past would change his mind in a future case. Unless the challenging party could prove specific facts, which prove the arbitrator's prejudice, the assumption that "he is a legal professional with the ability to keep a professional distance" would act in his favor. ${ }^{376}$

372 Saba Fakes v Turkey, ICsID Case No. ARB/o7/20, summarized in Sheppard, supra note 32, at 154 .

373 Referenced in Repsol, \ 23; see also Fry and Stampalija, supra note 31, at 246.

374 Saint-Gobain, $\mathbf{\Upsilon} \boldsymbol{\top} 16$ and 23.

375 Id. $₫ 25$.

376 Id. ๆ 81. 
The challenge in Urbaser was founded on the views Professor McLachlan had expressed in academic writings. His publications concerned the application of so-called most favored nation clauses to the dispute settlement provisions of a BIT, and the defense of necessity. In the Claimants' view, said publications proved that the arbitrator prejudged the issues at stake in the present case: ${ }^{377}$ Because he would not realistically express an opinion contrary to his own writings for fear of being criticized as being inconsistent, Professor McLachlan was inherently unfree in his decision-making. ${ }^{378}$ The unchallenged arbitrators dismissed the challenge. Framing the lack of independence and impartiality as the arbitrator's reliance on factors which have no relation to the merits of the case, ${ }^{379}$ they held that the opinions expressed in academic writings would have to be so specific and clear that an arbitrator could rely on them for deciding the case, without giving the parties' submissions due consideration. ${ }^{380}$ Otherwise, the academic debate on international investment law would be undesirably stifled and ICSID would be paralyzed by a multitude of challenges against arbitrators who have made contributions to the doctrinal discourse. ${ }^{381}$ Professor McLachlan's publications were held not to be of such a detailed and conclusive nature as to prevent him from taking the arguments of the parties into account. ${ }^{382}$

In Tanzania Electric, Judge Charles N. Brower resigned from his position on the tribunal after one of his law clerks had discussed the legal questions at issue online. The unchallenged arbitrators had apparently been unable to agree on the disqualification request. ${ }^{383}$

In summary, none of the challenges based on an arbitrator's prior familiarity with the relevant subject-matter were successful. The arbitrators' previous statements (as government officials or academics) were held to leave enough room for a dutiful consideration of the parties' submissions.

\subsection{Connection to an Adverse Third Party}

In fourteen instances, arbitrators were challenged because of their (direct or indirect) connection to an adverse third party, which was argued to cause them to be predisposed against the challenging party.

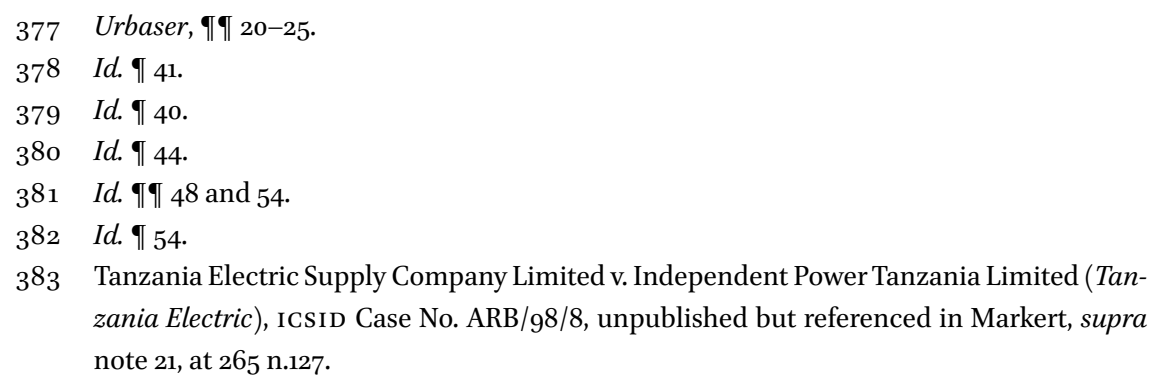


In ConocoPhillips I, Venezuela requested the disqualification of Yves Fortier, Q.C. His firm (Norton Rose LLP, hereinafter Norton Rose) had targeted Macleod Dixon LLP (hereinafter Macleod Dixon) as a target for a merger. The Caracas office of Macleod Dixon acted as counsel for Claimant in several cases directed against Venezuela and its State owned petroleum company. It was portrayed as the single most adverse law firm to Respondent's interests, whose case portfolio relied heavily on disputes against Venezuela. Even after Mr. Fortier's resignation from Norton Rose, Venezuela upheld its proposal for disqualification. ${ }^{384}$ It highlighted that Macleod Dixon's Caracas office and Mr. Fortier's arbitration expertise and practice were central assets in the merger, which could not be kept apart by ethical screens or by a resignation of Mr. Fortier. Respondent claimed that from the moment Norton Rose targeted Macleod Dixon as a merger partner, there was a risk of (conscious or unconscious) bias against Venezuela - irrespective of any ethical screens. Furthermore, the ethical walls were alleged not to function, since the two firms were apparently already working together on some files. ${ }^{385}$ The unchallenged arbitrators dismissed the challenge. Although they recognized Macleod Dixon's adverse position towards Venezuela, they believed Mr. Fortier's assurances that he did not have any knowledge of and was not involved in any proceedings against Venezuela. ${ }^{386}$ In the absence of sufficiently detailed knowledge about the merger and its target, Mr. Fortier could not possibly have been biased.

Mr. Fortier's relationship with Norton Rose has since given rise to seven more challenges. In ConocoPhillips III, IV, V and VI, Venezuela argued that Mr. Fortier's ongoing relationship with Norton Rose - in particular, his continued use of members of Norton Rose as tribunal assistants - casts doubts on his independence and impartiality.

To substantiate its allegation of an ongoing relationship, Venezuela referred to the notorious involvement of Mr. Martin Valasek (a partner at Norton Rose) in the Yukos arbitration, ${ }^{387}$ presided over by Mr. Fortier, in ConocoPhillips $I I I$ and $I V$. Russia's allegation that the historic USD 50 billion award in Yukos was not written by the tribunal, but by an assistant to the tribunal (namely

\footnotetext{
384 ConocoPhillips I, 9 - 11 and 15.

385 Id. ๆ $24-28$ and $30-31$.

386 Id. ๆ $63^{-6}-65$.

387 Hulley Enterprises Limited (Cyprus) v. Russian Federation (PCA Case No. AA 226), Yukos Universal Limited (Isle of Man) v. Russian Federation (PCA Case No. AA 227), and Veteran Petroleum Limited (Cyprus) v. Russian Federation (PCA Case No. AA 228).
} 
Mr. Valasek), had caused an outcry in the international arbitration community. ${ }^{388}$ While Mr. Valasek's role in Yukos was merely alleged in the third disqualification request, ${ }^{389}$ it was corroborated by a report of a linguistics expert (filed by Russia in set-aside proceedings of the Yukos awards) in the fourth disqualification proceeding. ${ }^{390}$ Venezuela reiterated that Norton Rose (including Mr. Valasek personally) represented companies adverse to Venezuela in cases involving the same critical issues as ConocoPhillips. Thus, the continued close professional relationship between Mr. Fortier and the law firm raised doubts about his independence and impartiality. ${ }^{391}$

Both challenges were dismissed. In ConocoPhillips III, the ICSID Chairman held that Mr. Fortier's continued use of Norton Rose employees as tribunal assistants had been disclosed in the context of the first disqualification proceeding, in 2011, and that the challenge was therefore untimely as far as it was based on this circumstance. ${ }^{392}$ Mr. Valasek's role in Yukos, on the other hand, was brought up in a timely manner, but unsubstantiated, and even if it were proven, would be irrelevant to the determination of Mr. Fortier's independence and impartiality. ${ }^{393}$

In ConocoPhillips IV, the unchallenged co-arbitrators decided that Mr. Fortier could not repeatedly be challenged based on the same facts. ${ }^{394}$ They did, however, seem to concede that Mr. Valasek's involvement in Yukos could be considered a new basis for a challenge, if it was established. Venezuela would then need to prove that "the particular collaboration with Mr. Valasek gives rise to a manifest lack of independence and impartiality in this case."395

In ConocoPhillips $v$, Venezuela argued that Mr. Fortier created "an impression of 'lesser ties to Norton Rose than actually existed,"396 by inaccurately disclosing the circumstances of a Norton Rose lawyer's appointment as an assistant to a tribunal he chaired. While he had only formally engaged Alison Fitzgerald

388 See Dmytro Galagan, The Challenge of the Yukos Award: an Award Written by Someone Else - a Violation of the Tribunal's Mandate?, Kluwer Arbitration Blog (Feb. 27, 2015), http://kluwerarbitrationblog.com/2015/02/27/the-challenge-of-the-yukos-award-an -award-written-by-someone-else-a-violation-of-the-tribunals-mandate/.

389 ConocoPhillips III, 994.

390 ConocoPhillips $I V, \mathbb{\Upsilon} 15$.

391 Id. ๆ 25.

392 ConocoPhillips III, ๆ 66.

393 Id. ๆ 95.

394 ConocoPhillips IV, ๆ

395 Id. \ 40.

396 ConocoPhillips $v$, 925. 
as a tribunal assistant after he had left Norton Rose, he falsely disclosed that she was appointed prior to his resignation, "when she was a very junior lawyer with Ogilvy Renault."397 Ogilvy Renault, the predecessor of Norton Rose, was renamed on June 1, 2011. Thus, Mr. Fortier's disclosure implied that Ms. Fitzgerald was appointed prior to that date, while her appointment effectively only took place in February 2012. ${ }^{398}$ Venezuela did not explicitly accuse Mr. Fortier of misrepresenting or concealing these facts, but intimated that he had downplayed his continuing ties with Norton Rose, which had been at the core of the prior three disqualification requests. ${ }^{399}$ The unchallenged arbitrators dismissed the request, considering the inaccuracies in Mr. Fortier's disclosure to be negligible: While his erroneous reference to Norton Rose as Ogilvy Renault is not mentioned in the decision, the appointment of Ms. Fitzgerald after Mr. Fortier's resignation from Norton Rose is regarded as insignificant, since the "substantive decision was made by the three arbitrators in December 2011."400 The unchallenged arbitrators further recalled their decision in ConocoPhillips $I V$, denying the admissibility of repetitive challenges. ${ }^{401}$ Thus, Mr. Fortier's ties to Norton Rose could not serve as a basis for the challenge. Looking into the appointment of a Norton Rose lawyer as a tribunal assistant nevertheless, they held that it amounted to such a minor connection to Norton Rose, that no reasonable third person would conclude that Mr. Fortier manifestly lacks the requisite independence and impartiality. ${ }^{402}$

In ConocoPhillips VI, Venezuela substantiated its allegation of Mr. Fortier's continued involvement with Norton Rose by showing that his secretaries received insurance and other benefits from an entity set up by Norton Rose (Services OR LP/SEC). ${ }^{403}$ It argued that although Mr. Fortier reimbursed Services OR LP/SEC for the secretaries' salaries and benefits, the service arrangement provided him with substantial benefits, ${ }^{404}$ and belied Mr. Fortier's promise

\footnotetext{
397 Id. ๆ 6.

398 Id. 97.

399 According to Venezuela, the "pattern of non-disclosure, or simply inaccurate disclosure" raised doubts as to Mr. Fortier's impartiality (id. \ 24), "because it created an impression of lesser ties to Norton Rose than actually existed"” (id. ๆ 25).

$400 \quad$ Id. ๆ 34.

401 ConocoPhillips IV, I 37 ("a challenge based on the same facts cannot be presented again"). Since Mr. Fortier's continued use of Norton Rose employees as tribunal assistants had been disclosed in the first disqualification proceeding, in 2011, the Respondent was held not to have produced new facts.

$402 \quad I d .935$.

403 ConocoPhillips VI, $₫ 6$.

404 Id. 96.
} 
of severing all financial and professional ties to Norton Rose. ${ }^{405}$ Moreover, Mr. Fortier had failed to disclose this continuing relationship with Norton Rose, thus (once more) raising doubts about his independence and impartiality. ${ }^{406}$ Again, the unchallenged arbitrators dismissed the proposal for disqualification. They held that Respondent failed to show how the service arrangement a purely administrative tie with Norton Rose - would affect Mr. Fortier's independence and impartiality in the specific case at hand. ${ }^{407}$ The inadmissibility of repetitive challenges was highlighted once more, ${ }^{408}$ serving as a basis to summarily dismiss the Respondent's proposal. ${ }^{409}$

The disqualification requests in Favianca were closely related to the ConocoPhillips challenges: Venezuela's request for a disqualification of Mr. Fortier in Favianca $I^{410}$ was based on the same circumstances as the challenges in ConocoPhillips III and IV. In particular, Venezuela pointed out the ongoing (informal) relationship between Mr. Fortier and his former law firm, Norton Rose, and the controversial role of one of Norton Rose's partners, Martin Valasek, in the Yukos case. ${ }^{411}$ It further explained that Mr. Fortier continued to occupy offices in the same building as Norton Rose, "in the reception area" of the firm, that he still had a Norton Rose email address, and that he had publicly endorsed one of Norton Rose's lawyers in her political candidacy. ${ }^{412}$ These circumstances, Venezuela argued, raised justifiable doubts about his ability to independently and impartially decide cases which would impact Norton Rose and its clients. ${ }^{413}$ The ICSID Chairman dismissed the challenge as belated:

\footnotetext{
405 Id. 99.

$406 \quad I d .96$.

407 Id. ๆ $14-16$.

408 Id. $\ 17$.

409 Mr. Fortier's unique position as the sole beneficiary of staff and administrative support services provided by Services OR LP/SEC (apart from Norton Rose) was not addressed by the unchallenged arbitrators. The same applies to his failure to sever all ties with Norton Rose, and the impact this has on his credibility.

410 Fábrica de Vidrios Los Andes, C.A. and Owens-Illinois de Venezuela, C.A. v. Bolivarian Republic of Venezuela (Favianca I), ICSID Case No. ARB/12/21, Decision on the Proposal to Disqualify a Majority of the Tribunal (June 16, 2015). At the same time, Venezuela also challenged the arbitrator appointed by itself, Alexis Mourre, based on his consultancy agreement with Dechert LLP, a law firm which was at the time adverse to Venezuela in six unrelated litigation proceedings (id. \ 20). Mr. Mourre resigned, and the challenge became moot.
}

411 Id. ๆ| 23-24.

412 Id. ๆ 26.

413 Id. ๆ 27. 
Venezuela should have been aware of the relationship between Mr. Fortier and Mr. Valasek by July 2014. While it only learned of Mr. Valasek's controversial role in Yukos in January 2015, it was able to file its disqualification request in ConocoPhillips III on February 6, 2015. The challenge in Favianca I, however, was not filed until thirty-five days later, on March 13, $2015 .{ }^{414}$

The challenge in Favianca II was based on arguments similar to those in ConocoPhillips $v$ : The engagement of a Norton Rose lawyer as a tribunal assistant, after Mr. Fortier's resignation from Norton Rose, and despite his assurances to sever all ties with the firm upon his resignation, was claimed to raise doubts regarding his independence and impartiality. These doubts were alleged to be further exacerbated by his inaccurate disclosure. The challenge was dismissed by the unchallenged arbitrators, who held that the understanding between Norton Rose and Mr. Fortier (which provided for the continued service of Norton Rose lawyers on tribunals, as well as their replacement by other Norton Rose lawyers ${ }^{415}$ ) was not of a nature or intensity to lead a reasonable third person to conclude that Mr. Fortier's interests were so aligned with those of Norton Rose that he would be unable to exercise free judgment. ${ }^{416}$ Since the tribunal assistant's involvement was irrelevant for Mr. Fortier's independence and impartiality, its date was held to be a priori negligible, and the inaccuracy of Mr. Fortier's disclosure (which a reasonable third person would believe to be an oversight) thus forgivable. ${ }^{417}$

The facts underlying the challenge in Favianca III were similar to those invoked in ConocoPhillips vI: The Respondent showed that Mr. Fortier's secretaries received insurance and other benefits from an entity set up by Norton Rose (Services OR LP/SEC), and that one of them (Myriam Ntashamaje) was employed by Norton Rose, according to her LinkedIn profile. Like all other challenges of Mr. Fortier, the proposal for disqualification in this case was dismissed. The unchallenged arbitrators held that a reasonable third person in possession of Ms. Ntashamaje's LinkedIn page, as well as Mr. Fortier's clarifications (according to which she is not, and never was employed by Norton Rose), would believe him and conclude that the secretary committed an error. ${ }^{418}$

\footnotetext{
414 Id. $ๆ$ ๆ $41-46$.

415 Favianca II, 944.

416 Id. $\ 49$.

417 Id. 957.

418 Favianca III, ๆ 53-54 ("[W]ould a third party in possession of Ms. Myriam Ntashamaje's LinkedIn page and Mr. Fortier's subsequent clarification in relation to the information displayed on that LinkedIn page conclude that Ms. Myriam Ntashamaje had committed
} 
The administrative handling of Mr. Fortier's secretaries' salaries and benefits by Services OR LP/SEC was held to be a financially neutral arrangement, which did not give the challenged arbitrator a direct financial interest in the activities of Norton Rose. While the arrangement was convenient for Mr. Fortier, it did not lead to an alignment of his interests with Norton Rose which would cause a reasonable third person to entertain serious doubts as to his reliability for independent and impartial judgment. ${ }^{419}$

In Saint-Gobain, Claimant challenged Gabriel Bottini based on his connection to Osvaldo Guglielmino, who now represented Venezuela in a parallel proceeding. ${ }^{420}$ At the time of his appointment, the arbitrator was an employee of the Argentinian Attorney General, under direct supervision of Mr. Guglielmino. Now, the former co-workers found themselves involved in parallel unrelated proceedings involving the same Respondent, as arbitrator and as counsel. The unchallenged arbitrators did not consider this situation problematic, highlighting that Mr. Guglielmino had ceased to be Mr. Bottini's superior three years earlier, and that the two had not seen each other more than twice since. ${ }^{421}$

The challenge of Robert von Mehren in Cemex was dismissed by the unchallenged arbitrators because it was belated. ${ }^{422}$ The request had been based on the connection between the arbitrator and a law firm adverse to Venezuela in a parallel proceeding. In particular, Robert von Mehren was a retired partner of the law firm Debevoise \& Plimpton LLP. Even after his retirement,

an error, or would that person conclude that Mr. Fortier has deliberately misrepresented the true state of affairs concerning Ms. Myriam Ntashamaje's employment to the Two Members, the Parties and ICsID in full knowledge that his clarification will be recorded in a decision that will be made public and that the contents of his representation are easily susceptible to verification by the public? ... [T] here can be no doubt [that] a reasonable third person would conclude that Ms. Myriam Ntashamaje had committed an error on her LinkedIn page and that the true state of affairs is that she has been employed by Cabinet Yves Fortier throughout the relevant period.").

419 Id., ๆ 59-6o.

420 Flughafen Zürich A.G. and Gestión e Ingenería IDc S.A. v. Bolivarian Republic of Venezuela, ICSID Case No. ARB/10/19.

421 Saint-Gobain, If 87. See supra Part 2.3 for the unchallenged arbitrators' argumentation with regard to the pleaded "issue conflict".

422 CEMEX Caracas Investments B.V. and CEMEX Caracas II Investments B.V. v. Bolivarian Republic of Venezuela (Cemex), ICSID Case No. ARB/o8/15, Decision on the Respondent's Proposal to Disqualify a Member of the Tribunal (Nov. 6, 2009), 944. 
he maintained offices and used secretarial services at the firm. ${ }^{423}$ Debevoise \& Plimpton LLP concurrently represented the Claimant in Holcim, ${ }^{424}$ an investor-State action against Venezuela arising out of the same general set of facts. ${ }^{425}$

In Getma, the request for disqualification was based on the arbitrator's brother's simultaneous appointment in a parallel proceeding involving the same Claimant and concerning the same facts. ${ }^{426}$ The unchallenged arbitrators dismissed the request for disqualification, stating that the apprehension of bias was based on mere speculations. Other than the family tie between the two brothers involved in the arbitrations, the challenging party would have to establish further facts from which a manifest lack of independence or impartiality could reasonably be inferred. ${ }^{427}$ The root concern in this case appears to have been consistency with other challenge decisions: If the nomination of the same arbitrator in concurrent proceedings on similar issues was not challengeable, ${ }^{428}$ the nomination of two brothers could not, a fortiori, be considered problematic. ${ }^{429}$

Romania's disqualification request in $S \& T$ Oil did not need to be resolved: With the consent of his co-arbitrators, Mr. Savage voluntarily resigned. ${ }^{430}$ Romania had argued that the representation of a foreign investor in an unrelated proceeding against Romania by Mr. Savage's firm raised doubts about his independence and impartiality. ${ }^{431}$

In EDF and in Suez II, Argentina challenged Professor Kaufmann-Kohler based on her position as a director of UBS. UBS itself was not involved in the proceeding, but had recommended investments in the parent company of one of the Claimants in $E D F$ and was a minority shareholder of two of the Claimants

\footnotetext{
423 Id. ๆ 21-22.

424 Holcim Limited, Holderfin B.V. and Caricement B.V. v. Bolivarian Republic of Venezuela, ICSID Case No. ARB/og/3.

425 See Bernasconi-Osterwalder, Johnson, and Marshall, supra note 32, at 20.

426 Getma, 9 10. The parallel proceeding was initiated by Getma against Guinea in the Common Court of Justice and Arbitration (CCJA), a court and arbitration institution responsible for supervising the administration of arbitration proceedings in member States of the Organisation for the Harmonization of Business Law in Africa (Organisation pour l'Harmonisation en Afrique du Droit des Affaires, OHADA).

427 Id. ๆ $68-72$.

428 See Tidewater, supra note 160.

429 Getma, 974.

430 S \& T Oil Equipment and Machinery Ltd. v. Romania, ICSID Case No. ARB/o7/13, Order of Discontinuance of the Proceeding (July 16, 2010), ๆ 14.

431 Bernasconi-Osterwalder, Johnson, and Marshall, supra note 32, at 18.
} 
in Suez II. Argentina argued that the arbitrator's position would cause her to have a personal (economic) interest in the outcome of the proceeding, and prevent her from adjudicating the case independently and impartially.

In $E D F$, the recommendation by UBS of investments in EDF's parent company and its common interest in several companies with EDF were central arguments brought forward by Argentina ${ }^{432}$ along with the partial dependence of Professor Kaufmann-Kohler's remuneration on the success of UBs. ${ }^{433}$ An expert opinion submitted by Respondent explained that there was an economic incentive for UBS to favor Claimants, and that as a consequence, "Professor Kaufmann-Kohler's 'loyalty interests' will lead her to follow suit," irrespective of the relative size of UBs's holdings in EDF. ${ }^{434}$ In other words, Argentina argued that Professor Kaufmann-Kohler's role as a director of U BS and her role as an arbitrator were irreconcilable, because she could not fulfill any one of her duties without breaching the other one. The co-arbitrators dismissed the challenge. They denied that Professor Kaufmann-Kohler had a financial interest or other benefit that would depend on the outcome of the case $^{435}$ and declared the Respondent's apprehension of her emotional solidarity or psychological identification with UBs, and thus with Claimants, to be "remote, tenuous and speculative." 436 A significant part of the case hinged on Professor Kaufmann-Kohler's failure to disclose the connection between UBS and EDF, which she apparently did not know of. Argentina argued that the arbitrator breached her duty to investigate potential conflicts of interest. The co-arbitrators dismissed this argument, reasoning (very cursorily) that "[w]hatever level of disclosure might be required under the ICsid Convention, a failure to inform the parties about this Board membership does not rise to that plane." ${ }^{437}$

In Suez II, the connection between UBS and Claimants was even more direct. In addition to recommending the investment in the companies as in $E D F$, UBS was a minority shareholder of two of the Claimants. ${ }^{438}$ Again, a part of

432 UBS was claimed to hold $5 \cdot 32 \%$ of the shares of a company effectively controlled by Claimant through an intermediary; it further sold shares of another company (in a proportion of $17.3 \%$ and later another $17.32 \%$ ) directly to Claimant. $E D F, \boldsymbol{q} 12$.

$433 E D F$, ๆ 28.

434 Id. ๆ

435 Id. $₫$ ๆ $71,96$.

436 Id. ๆ 73. See also id. ๆ 76 , 121. The co-arbitrators held that the $1.5 \%$ stake of U Bs in AEM was de minimis.

$437 \quad I d .998$.

438 Suez, Sociedad General de Aguas de Barcelona S.A. [hereinafter Suez] and Vivendi Universal S.A. [hereinafter Vivendi]. 
Professor Kaufmann-Kohler's remuneration was in UBS shares, and all of these facts remained undisclosed. ${ }^{439}$ The unchallenged arbitrators held that the connection between the arbitrator and two of the Claimants was insufficient in and of itself, and that it had to be evaluated qualitatively, based on four criteria: proximity, intensity, dependence and materiality. ${ }^{440}$ Applying those four criteria, and focusing on the market value of the shares in Suez and Vivendi held by UBS, compared to the total amount of assets it manages, the unchallenged arbitrators found that any potential effect of the connection between Claimants and UBS on the award was negligible, since the economic benefit for Gabrielle Kaufmann-Kohler was not material. ${ }^{411}$ The Respondent's claim of a breach of the duty to investigate and disclose potential conflicts of interest was decided very similarly to $E D F .442$

In summary, none of the arbitrator challenges based on an arbitrator's connection to an adverse third party were upheld.

\subsection{Conclusion}

The above analysis of the presently available ICSID disqualification decisions indicates that a vast majority of arbitrator challenges is based on the arbitrators' familiarity with another participant in the proceeding. Repeat appointments by the same Respondent State or law firm, or against the same Respondent State are particularly frequently invoked as a basis for challenge.

Practically all of these disqualification requests are dismissed, irrespective of the standard of independence and impartiality applied. Throughout all case categories, the burden of proof imposed on the challenging parties is very high and rarely met. The "reasonable doubts regarding the appearance" standard established in Vivendi is often pared down with further requirements, effectively bringing it ever closer to the Amco Asia standard.

439 In the case at hand (Suez II), UBs held a 2.1 / 2.38\% interest in two of the corporate Claimants, Suez and Vivendi. Suez II, ๆ 1 12, 31.

$440 \quad I d .9$ ๆ $32-35$.

441 Id. ๆ 36 -37. The co-arbitrators highlighted that there was no evidence that the award would impact the market price of the Claimant companies, and that the award's effect on the "fortunes of UBS" was likely negligible.

442 Id. ๆ $46-48$. The failure to disclose the bank's interest in two of the Claimants in and of itself was not considered a sufficient ground for a challenge, because Professor Kaufmann-Kohler had instructed uBs to conduct a conflict check. UBs did not disclose its shareholdings in the Claimants, and the arbitrator relied on the information received. According to the co-arbitrators, such reliance was an "honest exercise of judgment and not part of a pattern of circumstances raising doubts about impartiality". 
Challenges based on the familiarity of an arbitrator with another participant in the proceeding (in particular repeat appointments) or with the subjectmatter at issue are generally dismissed, unless the parties, facts and legal issues of the relevant cases overlap to a significant degree. This requirement is an additional obstacle for challenging parties, which the Vivendi standard does not logically imply: Justifiable doubts as to an arbitrator's lack of independence and impartiality cannot only arise when an arbitrator has dealt with a virtually identical case in the past, but also (for example) where he or she has dealt with the same legal questions, arising from different legal sources, and if the facts were merely similar. Whether the parties were the same is secondary. Accordingly, this additional requirement appears excessive. Aside from being irreconcilable with the Vivendi standard, any such rigid prerequisite is unlikely to do justice to the particularities of every single case.

Furthermore, decision-makers have repeatedly been reluctant to assume an overlap of the pertinent facts and legal bases when these issues have not yet been pleaded, making it very difficult for the challenging party to properly time its request for disqualification and avoid its dismissal for being belated. This is another reason why the Vivendi standard should not be ratcheted up with additional requirements which can hardly ever be met.

Quite frequently, arbitrators' assurances of independence and impartiality, their experience and reputation, and their general character are referenced to justify the dismissal of disqualification requests. These factors, however, are not only irrelevant under widely accepted definitions of arbitrators' independence; ${ }^{443}$ they should also be insignificant based on insights from the field of cognitive psychology. ${ }^{444}$

In a number of disqualification decisions, the circumstances set forth by a challenging party as a basis for the inference of a lack of independence or impartiality were considered insufficient, in and of themselves. Despite being

443 Independence is defined objectively, as the absence of certain critical relationships, irrespective of their actual effect on the arbitrator in question. See Schreuer Et AL., CoMMENTARY, supra note 16, Art. 40, 121 (considering the arbitrator's general moral character to be equally unsubstantial); Rubins and Lauterburg, supra note 32, at 155; BLACKABY ET AL., supra note 9o, 9 4.77; SCHWARTZ AND DeRAINS, supra note 87, at 117.

444 See, e.g., Rogers, Eтhics, supra note 98, ๆ | 8.55-8.56 ("It is important to stress that the propensity to engage in Groupthink does not reflect on arbitrators' intelligence, earnestness, or diligence. It is a by-product of human decision-making in group settings .... [T] hese psychological phenomena are not generally a matter of choice. Studies indicate that we are all, to some degree, subject to ... shortcomings and shortcuts to decision-making."). 
based on facts which were not refuted by the counterparty, the decision-makers often labelled such circumstances as "mere supposition and speculation," which should have been backed up with more evidence. Various categories of facts are being carved out as inadequate factual bases for disqualification requests (i.e. family ties, repeat appointments, and the acquaintance of an arbitrator with one of the counsel). This list is non-exhaustive and continually expanded, leading to a significant degree of legal uncertainty.

In general, decision-makers in arbitrator challenges are extremely reluctant to uphold disqualification requests. This does not only apply to the unchallenged co-arbitrators, but also to the ICSID Chairman and the SecretaryGeneral of the PCA. Their reasoning suggests that the tight network and the centrality of certain arbitrators are generally considered to be inherent in the system. ${ }^{445}$ As a consequence, previous contacts of an arbitrator with a party (including attorney-client relationships) or counsel (including law firm collaborations), the switching of roles between arbitrators and counsel, and repeat appointments ${ }^{46}$ are presumed to be harmless. Only very rarely and under extraordinary circumstances are challenges based on such grounds ever successful.

Even in challenge decisions where the wording of the applicable challenge threshold would imply a lower burden of proof on the challenging party, and a stricter approach to arbitrators' independence and impartiality, the outcomes of the requests and the decision-makers' reasoning do not reflect the lower threshold. This raises the question whether the ICSID standard for arbitrator challenges has only ostensibly been aligned with other standards for arbitrator challenges ${ }^{447}$ - as a response to doctrinal calls for a stricter standard of independence and impartiality.

To sum up, arbitrators are effectively unlikely to be disqualified unless the challenging party can prove their actual bias, even under the Vivendi standard. This expectation is incredibly high and unrealistic. ${ }^{448}$ The few cases in which arbitrators were disqualified appear to be singular exceptions to this rule.

445 Tidewater, ๆ 68; see also Universal Compression, ๆ 83.

446 Unless they are made by the same party, and in cases in which the facts and the law are essentially the same. See Caratube.

447 See infra Chapter 3.

448 Luttrell, supra note 31, at 220 and 224; SCHREuer ET AL., Commentary, supra note 16, Art. 57, If 19; Van Harten, Procedural Fairness, supra note 26, at 651; Van Harten, Perceived Bias, supra note 39, at 439; REED, PAUlsson, AND BlACKABy, supra note 13, at 134; Sheppard, supra note 32, at 138; Fry and Stampalija, supra note 31, at 256. 


\section{$3 \quad$ Factors Underlying the Prevalent Dismissal of Arbitrator Challenges}

Three factors contribute to the strict approach to arbitrator challenges and their prevalent dismissal:

First, the uniqueness of the terminology used in Article 57 ICsID Convention, namely the requirement of a "manifest lack of the qualities required by paragraph (1) of Article 14," appears to suggest that disqualification proposals under the ICSID Convention are subject to a higher threshold than comparable requests in other dispute settlement mechanisms. While this interpretation appeals to intuition, it is wrong in light of contrary indications in the drafting history of the ICSID Convention. Although the meaning of the manifest lack requirement itself was never discussed during the drafting process, the drafting records document that the Convention did not intend to raise the bar for arbitrator challenges. On the contrary, Article 57 ICSID Convention was specifically introduced in order to provide for the disqualification of biased or dependent arbitrators.

Second, by default, disqualification requests are adjudicated by the unchallenged co-arbitrators. This could contribute to an elevation of the threshold in several respects. In particular, co-arbitrators might be overly protective of each other, ${ }^{449}$ to the point that this raises concerns about cronyism. ${ }^{450}$ In order to avoid disqualifying their colleagues, they might be tempted to impose additional requirements on disqualification proposals. Aside from the effect of such sympathies, the co-arbitrators may be so used to certain customs in the field of arbitration (such as role switching and repeat appointments), that they are unable to examine a disqualification proposal from the perspective of an (uninvolved) reasonable third person. They are more likely to find certain connections between arbitrators and other participants in the proceeding to be inherent in the system, or a necessary consequence of the characteristics of arbitration, and to dismiss doubts about an arbitrator's independence or impartiality on this basis.

This leads to the third factor for the predominant rejection of disqualification requests: Arbitrator challenges are often dismissed because their factual

449 Markert, supra note 21, at 248-250 (including further references); Fry and Stampalija, supra note 31, at 257-258; Tupman, supra note 43, at 32; Reinisch and Knahr, supra note 24, at 123; Nadakavukaren Schefer, supra note 82, at 233 ("In the small world of international arbitrators, disqualifying a fellow arbitrator on 'mere appearances' may not be well-regarded.").

450 Giorgetti, Challenges, supra note 32, at 316-317; Rubins and Lauterburg, supra note 32, at 163 . 
bases are perceived to be commonplace, inherent in the system, and inevitable in arbitration. This argument has been invoked to carve out entire categories as valid bases for inferences of bias. ${ }^{451}$ While it is correct that accidental contacts or a minimal degree of familiarity between appointing parties (or their counsel) and arbitrators are inevitable in investment arbitration, this truism is often contorted in challenge decisions, and invoked to justify circumstances which surpass unavoidable, systemically intrinsic or necessary side effects of central characteristics of arbitration.

For example, characteristic features of investment arbitration - such as the small community of investment arbitration professionals, the dual roles of arbitrators, and the global operations of law firms - increase the likelihood of an arbitrator's coincidental prior contacts with a party or its counsel, and the characteristically repetitive legal issues heighten the chances that an arbitrator has dealt with the same legal question before. Such situations should not automatically lead to a disqualification, and cannot per se constitute incompatibilities. The examined challenge decisions, however, go further than this: By only considering an arbitrator's ties to a party or counsel, or her or his familiarity with the subject-matter of the proceeding a sufficient basis for removal in the most extraordinary cases, they effectively establish a presumption of the harmlessness of such connections. ${ }^{452}$ This is wrong in light of Article 14 para. 1 ICSID Convention, which guarantees the parties' access to independent and impartial decision-makers.

Furthermore, in practice, only very few challenges are based on accidental overlaps of an arbitrator's past and current legal work or connections. Challenges are more often based on facts which the appointing party was well aware of, and which shaped its decision to appoint a particular arbitrator. An arbitrator's previous familiarity with a party or counsel, or with the subjectmatter of the case, is usually a factor which is diligently considered (or even sought out) by the appointing party, which is believed to be indicative of the arbitrator's relatively predictable position, and in the appointing party's favor. Such circumstances are not coincidental and inevitable side effects of characteristic features of arbitration, but strategic factors in party-appointments.

451 See, e.g., Tidewater, ๆ 68; Universal Compression, ๆ 83; Amco Asia, ๆ 7 7-8, referenced in Tupman, supra note 43, at 45 ("a party-appointing system inherently presumes some acquaintance between the party and its appointed arbitrator, and therefore 'leads necessarily to the consequence' that an arbitrator cannot be disqualified 'for the only reason that some relationship existed between that person and a party, whatever the character - even professional - or the extent of said relations."”).

$45^{2}$ See also DAELE, supra note $5^{1}$, 9 5-034. 
With regard to a majority of challenges, "inherent in the system" therefore does not refer to fortuitous consequences of the frequently invoked small size of the community, or the narrow set of legal issues. Instead, it points to the parties' purported right to freely appoint their decision-makers. As has been shown above, however, there is no such right. ${ }^{453}$ The parties are only entitled to appoint their decision-makers within the limits of Article 14 para. 1 ICSID Convention, i.e. subject to the appointees' independence and impartiality. Thus, only prior familiarities which are necessary to assess an arbitrator's suitability and qualifications, and which do not impair the arbitrator's independence and impartiality are intrinsic to the system of party-appointments, and innocuous. In other words, the argument of system inherence does not justify the dismissal of arbitrator challenges, if the established facts raise justifiable doubts about an arbitrator's lack of independence and impartiality. The standard is not whether a connection is accidental, or whether a circumstance is built-in to the system, but whether it raises justifiable doubts about the arbitrator's ability to evaluate the merits of the case open-mindedly, rationally, and objectively.

In summary, the unique requirement of a manifest lack of qualities under Article 57 ICSID Convention, the unusual authority of the co-arbitrators to decide on challenges, and the tension between characteristic features of arbitration and the requirement of independence and impartiality have led to an overly exacting approach to disqualification requests under the ICSID Convention. The precedence accorded to the parties' autonomy to select their decision-makers, at the expense of the appearance of independence and impartiality, endangers parties' confidence in the fairness and legitimacy of the mechanism. A clarification of the challenge threshold, a reassignment of the authority to decide challenges, and a clearer definition of the requirement of independence and impartiality would improve the perception of ICSID arbitration as a fair and law-based dispute settlement mechanism.

453 See Chapter 1, Part 2.2. 